\title{
DEVELOPMENTS IN RADIOCARBON TECHNOLOGIES: FROM THE LIBBY COUNTER TO COMPOUND-SPECIFIC AMS ANALYSES
}

\author{
Pavel P Povinec ${ }^{1} \cdot$ A E Litherland ${ }^{2} \bullet K^{K a r l ~ F ~ v o n ~ R e d e n ~}{ }^{3}$
}

ABSTRACT. We review developments in radiocarbon measuring techniques from the Libby counter through proportional gas counters and liquid scintillation spectrometers to the more recent developments of accelerator mass spectrometry (AMS), followed by a coupling of gas chromatography with AMS for compound-specific ${ }^{14} \mathrm{C}$ analyses. While during the first $60 \mathrm{yr}$ of ${ }^{14} \mathrm{C}$ measurements beta counting, specifically gas counting, was the dominant technique, in the future of ${ }^{14} \mathrm{C}$ science AMS will be the dominant technology.

\section{INTRODUCTION}

Analytical technologies have had always important impacts on the development of a new science and its applications. This has been especially true for radiocarbon science, which thanks to the great inventions of Willard Libby, both in formulating its principles and in developing necessary analytical techniques (Libby 1955), has become after $60 \mathrm{yr}$ of studies a well-organized and rapidly developing field. This has also been partly thanks to the Radiocarbon journal, which during its $50 \mathrm{yr}$ has developed from originally a data-reporting journal to its present form as a comprehensive information medium for cosmogenic research.

The isotope ${ }^{14} \mathrm{C}$ of carbon was discovered by beta-ray counting and was later observed to have a long half-life of $5730 \mathrm{yr}$. It was also found to be present naturally at a measurable level of about 15 beta-ray emissions per minute per gram of carbon, and this was followed by the bold proposal by Willard Libby (1946) that it could be used for dating the past. Dating was then demonstrated by patiently counting the number of beta-rays emitted from a known mass of historical carbon in a given time and using the laws of radioactive decay to determine the age relative to the half-life of ${ }^{14} \mathrm{C}$. This demonstration was impressively successful and launched ${ }^{14} \mathrm{C}$ dating by beta-ray counting. As the method depended upon the constancy of the generation of ${ }^{14} \mathrm{C}$ in the atmosphere by cosmic rays, such a demonstration was necessary and the skeptics were partly correct in that the cosmic-ray intensity does vary with time. However, even with the addition of anthropogenic ${ }^{14} \mathrm{C}$ from nuclear fission and fusion neutrons, released during nuclear weapons tests (Münnich and Vogel 1958; Nydal and Lövseth 1965), the method flourished as ways were found to surmount the problems (Olsson 1970).

There have been several important breakthroughs in ${ }^{14} \mathrm{C}$ technologies, starting from the Libby counter, followed by proportional gas counters, liquid scintillation spectrometers, and finally the development of accelerator mass spectrometry (AMS), which has shifted the analytical concept from counting of ${ }^{14} \mathrm{C}$ decay products (and waiting for beta-electrons) into direct counting of ${ }^{14} \mathrm{C}$ atoms present in a sample. As the half-life of ${ }^{14} \mathrm{C}$ is relatively long, the number of ${ }^{14} \mathrm{C}$ atoms present in a sample compared to the number of ${ }^{14} \mathrm{C}$ beta-decays observed during 1 day of counting is $\sim 3 \times$ $10^{6}$, significantly favoring the use of AMS. Recently, we have developed into a stage when bulk sample analysis has been replaced by compound-specific analysis, e.g. in gas chromatography-AMS coupled analytical systems, which has opened new dimensions in ${ }^{14} \mathrm{C}$ science.

\footnotetext{
${ }^{1}$ Comenius University, Faculty of Mathematics, Physics and Informatics, SK-84248 Bratislava, Slovakia. Corresponding author. Email: Povinec@fmph.uniba.sk.

${ }^{2}$ University of Toronto, IsoTrace Laboratory, Toronto, Ontario M5S 1A7, Canada.

${ }^{3}$ Woods Hole Oceanographic Institution, National Ocean Sciences AMS Facility, Geology and Geophysics Department, Woods Hole, Massachusetts 02543, USA.
} 
This review on ${ }^{14} \mathrm{C}$ technology developments is organized as follows: after discussing developments in beta-counting techniques (written by P P Povinec) we follow with developments of AMS (written by A E Litherland), and finally we describe recent developments in AMS, focusing on ocean science and compound-specific analysis (written by K von Reden).

\section{BETA-COUNTING TECHNIQUES}

\section{The Libby Counter}

After nuclear physics studies of ${ }^{14} \mathrm{C}$ properties (Kurie 1934; Bonner and Brubaker 1936; Burcham and Goldhaber 1936), its half-life (Ruben and Kamen 1941; Reid et al. 1946), the estimation of its production in the atmosphere by interaction of cosmic rays with nitrogen atoms (Libby 1946), and its observation in the environment in ${ }^{14} \mathrm{C}$-enriched biomethane (Anderson et al. 1947) at the predicted concentration, Libby $(1946,1955)$ came up with the idea to use cosmogenic ${ }^{14} \mathrm{C}$ for dating. Calculations showed, however, that ${ }^{14} \mathrm{C}$ activity in samples was very small, and the thermal diffusion enrichment was too complicated to be widely used for dating (Libby 1967).

A traditional method of activity measurement using a low-current ionization chamber would not give meaningful results. It was fortunate that gas counters for direct counting of pulses originating in the radiation detector as a result of radioactive decay of nuclei and emission of beta-particles were already in use (Geiger and Müller 1929). Willard Libby was well prepared for this task, as he already developed a screen-wall Geiger-Müller detector (Libby 1934), which he used for studying properties of soft beta-emitters, such as ${ }^{35} \mathrm{~S},{ }^{87} \mathrm{Rb}$, and others (Libby and Lee 1939), which were similar to that of ${ }^{14} \mathrm{C}$. Solid samples to be analyzed were internally attached to the detector body, and a mixture of 100 torr of argon and 5 torr of ethylene was used as a standard filling of the detector. Libby also used $\mathrm{CO}_{2}$ as an admixture to this standard counting gas (Engelkemeir et al. 1949); however, finally Libby decided to go to solid carbon, internally fixed on the detector wall, which allowed him to analyze bigger samples.

The method was not sensitive enough, however, as the counter background was too high, around 500 counts per minute (cpm). Inserting the counter inside a $20-\mathrm{cm}$-thick iron shield (to protect it against external radiation represented by cosmic rays and surrounding radioactive materials) decreased the detector background to $\sim 100 \mathrm{cpm}$. A further decrease by at least a factor of 10 was required as a count rate from a modern ${ }^{14} \mathrm{C}$ sample was expected to be $\sim 10 \mathrm{cpm}$. Libby recognized that the hard component of cosmic rays (muons) penetrating even the heavy iron shield should be at least partially eliminated to weaken their contribution to the detector background (Anderson et al. 1947). Such a trigger was used for the first time by Blackett and Occhialini (1933) to identify tracks of positrons in cosmic radiation by timing expansion of a cloud chamber. Libby found a revolutionary solution in using a similar tracking system, however, in an anticoincidence regime, which eliminated pulses coming from the central detector, if they were simultaneously registered by GeigerMüller tubes surrounding the central detector as a protective guard (Figure 1). This arrangement decreased the counter background by a factor of 20 (to $\sim 5 \mathrm{cpm}$ ), and was good enough to proceed with regular ${ }^{14} \mathrm{C}$ measurements.

Libby found that the simplest form of the ${ }^{14} \mathrm{C}$ sample inside the counter (Figure 2) would be a carbon cylinder, prepared from a sample (Anderson and Libby 1951; Anderson et al. 1951). He already knew that ${ }^{14} \mathrm{C}$ emits only low-energy beta-electrons, and therefore an external measurement would be very difficult. Such a simple solution was quite laborious as the counter should be opened and cleaned before introducing a new sample. However, he solved the problems with ${ }^{14} \mathrm{C}$ measurements, and the first ${ }^{14} \mathrm{C}$ data on biospherical samples (Anderson et al. 1951) and on ages of known samples were reported soon after (Arnold and Libby 1949). 


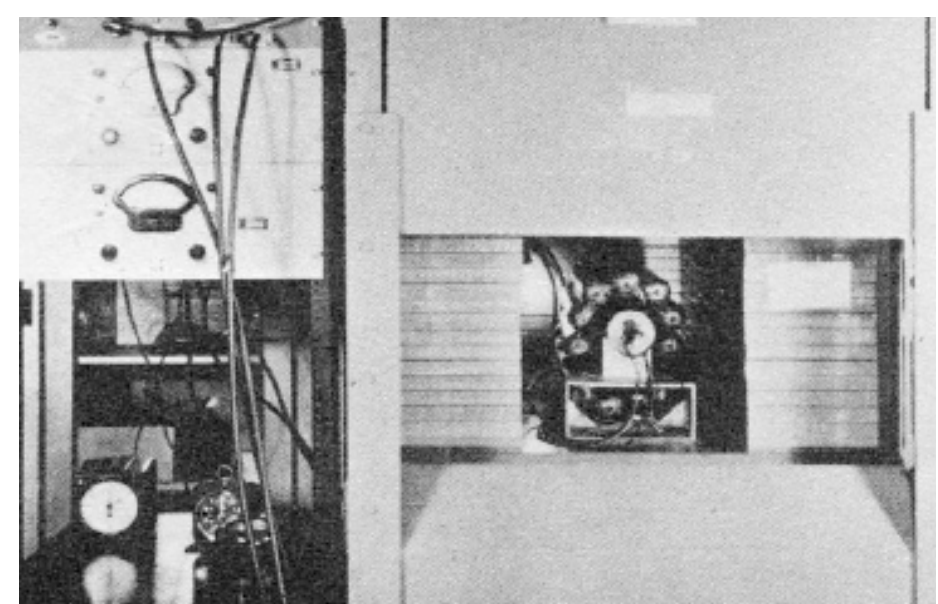

Figure 1 Libby's counting system with guard counters in anticoincidence (after Libby 1955).

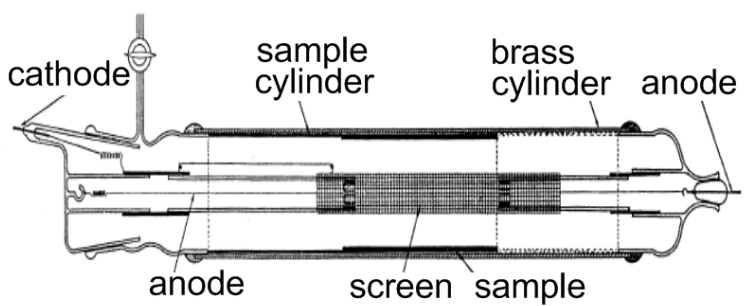

Figure 2 Libby screen counter with solid carbon sample (after Libby 1955).

\section{Proportional Gas Counters}

It has been clear from the beginning of ${ }^{14} \mathrm{C}$ measurements that for achieving larger ${ }^{14} \mathrm{C}$ data outputs and to ensure better precision, the Libby counter should be replaced by another type of a detector. Because of the low energy of ${ }^{14} \mathrm{C}$ beta-electrons (their maximum energy is only $156 \mathrm{keV}$ ), the best solution would be to incorporate a sample in a form of a gas directly into the sensitive volume of the detector. Therefore, it was natural to try carbon dioxide, the first product of sample combustion, which contains ${ }^{14} \mathrm{C}$ atoms from the sample. To assure the highest sensitivity, the best solution would be to use $\mathrm{CO}_{2}$ as a counting gas without any additives. It was already known (Curran et al. 1949) that single ions can be recorded in a proportional counter with better counting characteristics than in previously used Geiger-Müller counters.

After several trials, this had been achieved, although it was recognized that $\mathrm{CO}_{2}$ must be well cleaned to get reasonable counting characteristics (de Vries and Barendsen 1952, 1953). Almost simultaneously, Crathorn (1953) and Suess (1954) developed methods for preparation of acetylene, Burke and Meinschein (1955) for methane, and Faltings (1952) for ethane as suitable ${ }^{14} \mathrm{C}$ counting gases. However, $\mathrm{CO}_{2}$ became the most popular gas to fill proportional counters used for ${ }^{14} \mathrm{C}$ measurements, and several laboratories developed this technique almost simultaneously (Fergusson 1955; Brannon et al. 1955; Nydal and Sigmond 1957; Olsson 1957; Östlund 1957; Broecker et al. 1959). Even now, $\mathrm{CO}_{2}$ represents over $80 \%$ of the counting gases used in ${ }^{14} \mathrm{C}$ laboratories. 
The second piece of important information gathered during building of the first ${ }^{14} \mathrm{C}$ laboratories was the fact that only radioactivity-free construction materials must be used (e.g. quartz, electrolytical copper), especially for the construction of gas counters, if low background should be reached. Several such clean proportional counters were constructed, well shielded against the soft component of cosmic rays and surrounding radioactive sources by lead or iron passive shielding, accompanied by an active anticosmic shielding against the cosmic ray muons (e.g. Rafter and Fergusson 1957; Nydal 1962; Olsson et al. 1962; Oeschger 1963; Suess 1965; Damon et al. 1966; Povinec et al. 1968; Nydal et al. 1977; Stuiver et al. 1979; Schoch et al. 1980; Tans et al. 1982). These and many other ${ }^{14} \mathrm{C}$ laboratories have contributed significantly to ${ }^{14} \mathrm{C}$ science, especially to better understanding of the behavior of ${ }^{14} \mathrm{C}$ in the environment. Most high-precision ${ }^{14} \mathrm{C}$ results (a relative precision of $\Delta{ }^{14} \mathrm{C}$ of modern samples below $0.5 \%$ ) for the development of ${ }^{14} \mathrm{C}$ calibration curves were obtained using these types of detectors (e.g. Suess 1980; Stuiver et al. 1993; Stuiver and van der Plicht 1998; Kitagawa and van der Plicht 1998).

\section{Multiwire Guard Counters}

Another important development in the gas counting of ${ }^{14} \mathrm{C}$ was the introduction of a multiwire guard detector, connected in anticoincidence with the surrounding central (main) detector (Figure 3) (Raeth at al. 1951; Houtermans and Oeschger 1955; Drever et al. 1957; Nydal 1962; Geyh 1967; Povinec 1972a, 1992; Mościcki and Zastawny 1977; Srdoč et al. 1977). This helped to optimize the detector design as the inner cathode of the detector with proper thickness could be chosen from a material with a minimum radioactive contamination. The second advantage was in improving the efficiency of the cosmic-muon discrimination due to a better shielding of the central detector. If radioactively pure materials were used for the detector construction, especially for the inner cathode, it became possible to reach very low detector background $(<1 \mathrm{cpm} / \mathrm{L})$. If it was necessary to increase the detector sensitivity, the detectors could operate under higher than atmospheric pressure.
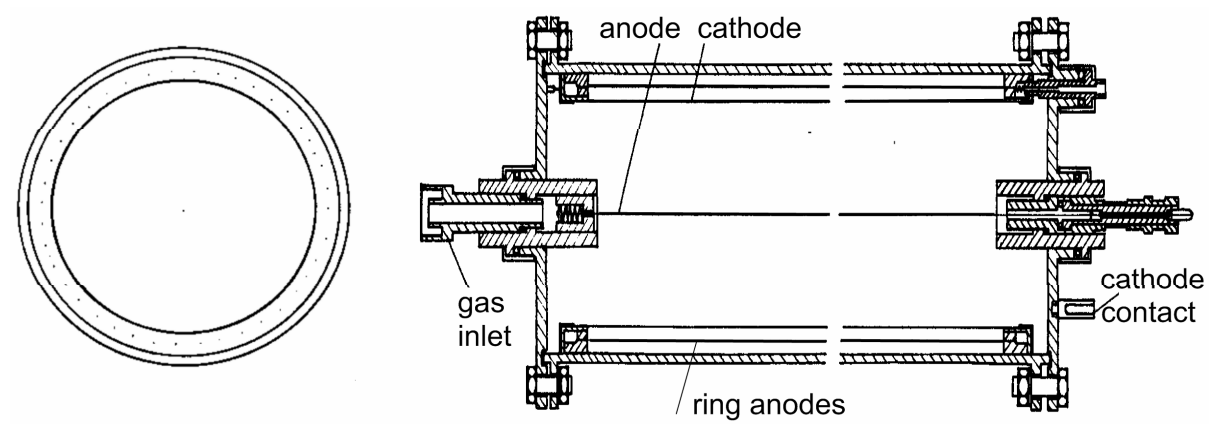

Figure 3 Proportional counter of the Oeschger type with a copper foil between the inner and the multiwire guard counter (after Povinec 1978).

By analysis of background components of a multiwire counting system, it has been found that the most important contribution to the background of the central detector is the thickness and the material of the inner cathode (Oeschger and Loosli 1977). The inner cathode should be very thin so the contribution of $\delta$-electrons originating in the cathode by interactions of gamma-rays with the cathode material should be minimized. The detector background can be expressed in the form (Oeschger and Loosli 1977):

$$
B+F_{\mu}+S F_{\alpha \beta}+\left(V \rho+\frac{S R_{p}}{4}\right) F_{n p}+\left(V \rho+\frac{S R_{e}}{4}\right) F_{\gamma e}
$$


where $F_{\mu}$ is the flux of unregistered muons; $S$ is the surface of the counter; $F$ is the flux of alpha and beta particles from the inner counter wall; $V$ is the counter volume; $\rho$ is the density of the counting gas; $R_{p}$ and $R_{e}$ are the average range of recoil nuclei and electrons, respectively; $F_{n p}$ is the flux of recoil nuclei from collisions with neutrons; and $F_{e}$ is the flux of gamma-induced secondary electrons.

A detector with the lowest background should have an optimized thickness of the inner cathode for stopping beta-electrons (originating from radioactive decay of ${ }^{14} \mathrm{C}$ nuclei) from the guard counter. In the case of ${ }^{14} \mathrm{C}$ beta-electrons, the optimum thickness is $\sim 10 \mathrm{mg} / \mathrm{cm}^{2}$. The cathode should be made, for example, from a radioactively pure organic foil with metal cover (gold-coated Mylar foil). Such an Oeschger counter (Geyh 1967; Oeschger and Wahlen 1975) with properly chosen construction materials reached a background below $1 \mathrm{cpm}$ per liter of sensitive volume. In the Bern underground laboratory (at $70 \mathrm{~m}$ of water equivalent [w.e.]), backgrounds of proportional counters with volumes between 0.02 and $1 \mathrm{~L}$ were further decreased by a factor of $2-4$.

As the Mylar foil is very fragile, another possibility is to use a thin foil made of electrolytical copper (Povinec 1978). A disadvantage of both designs is the need for a larger sample size, as the same gas filling is used in the both central and guard detectors. A separate filling and operation of the central and guard detector is possible (Charalambus and Goebel 1963); however, it requires a more complicated gas filling system.

\section{Microcounters}

It was recognized in the early stages of the development of proportional counters for ${ }^{14} \mathrm{C}$ measurements that this technique is specifically suitable for large volume samples. Typically, a 1-L counter filled with $\mathrm{CO}_{2}$ at atmospheric pressure would require a sample size of $0.5 \mathrm{~g}$ of carbon, which was a limiting factor in many investigations where usually milligram samples were only available, e.g. in archaeology.

Therefore, it was natural to look for small counters with volumes of the order of a few $\mathrm{mL}$, which would require only a few $\mathrm{mg}$ of carbon in the sample. Such small microcounters were developed for extraterrestrial and neutrino research (Stoenner et al. 1960), and later also for ${ }^{14} \mathrm{C}$ measurements (e.g. Geyh 1967; Currie et al. 1978, 1983; Harbottle et al. 1979; Loosli and Oeschger 1982; Hut et al. 1983; Srdoč et al. 1983). Figure 4 shows 2 of 6 microcounters placed in an anticosmic shield made of an $\mathrm{NaI}(\mathrm{Tl})$ scintillation detector (Otlet et al. 1983). A disadvantage of such measurements was the very long counting time, about 1 month. Although many counters can be running simultaneously, microcounters did not find widespread use, as AMS matured quickly to analyze very small samples with the required precision.

\section{Gas Fillings}

It has been fortunate that the most simple gas filling of a proportional counter, i.e. $\mathrm{CO}_{2}$, could be used for ${ }^{14} \mathrm{C}$ measurements. It was recognized from the beginning that $\mathrm{CO}_{2}$ requires special cleaning from impurities such as water vapors, nitrogen and sulfur oxides, and halogen compounds (de Vries and Barendsen 1953; Rafter and Fergusson 1957; Nydal 1962). Later, it was documented that this is due to $\mathrm{CO}_{2}$ sensitivity to electronegative impurities present in $\mathrm{CO}_{2}$ (Figure 5), which dramatically decrease the transit time of electrons from a place of their origin to the anode (Povinec 1979). The great advantage of $\mathrm{CO}_{2}$ filling was also the fact that the same $\mathrm{CO}_{2}$ sample was transferred to a mass spectrometer for measuring ${ }^{13} \mathrm{C} /{ }^{12} \mathrm{C}$ ratio without possible instrumentation change in the isotope ratio. 


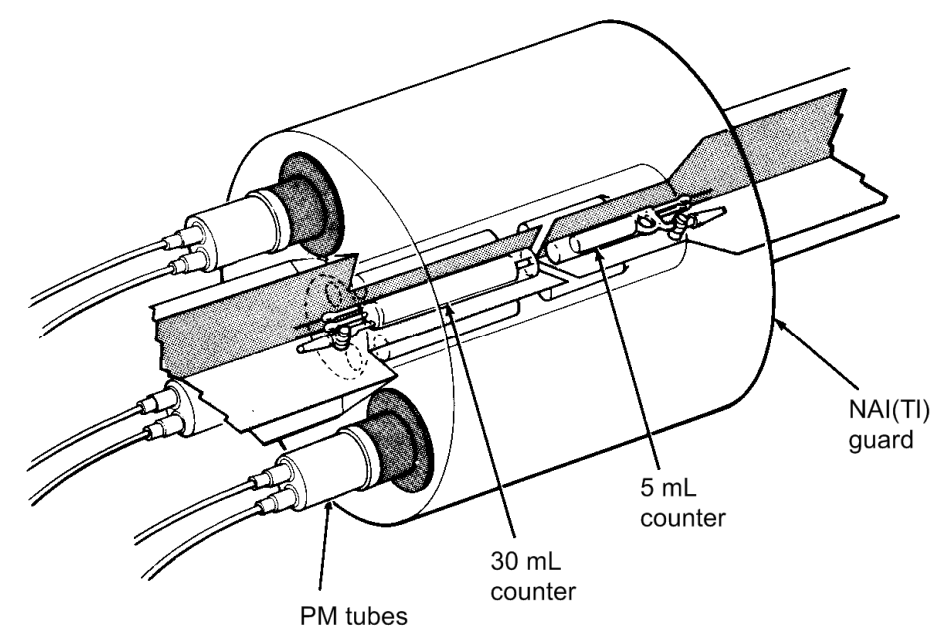

Figure 4 Assembly of 2 microcounters in 1 of the 6 compartments housing totally six $5-\mathrm{mL}$ and six $30-\mathrm{mL}$ counters shielded by a $305-\mathrm{mm}$-diameter and 305-mm-long $\mathrm{NaI}(\mathrm{Tl})$ detector (after Otlet et al. 1983).

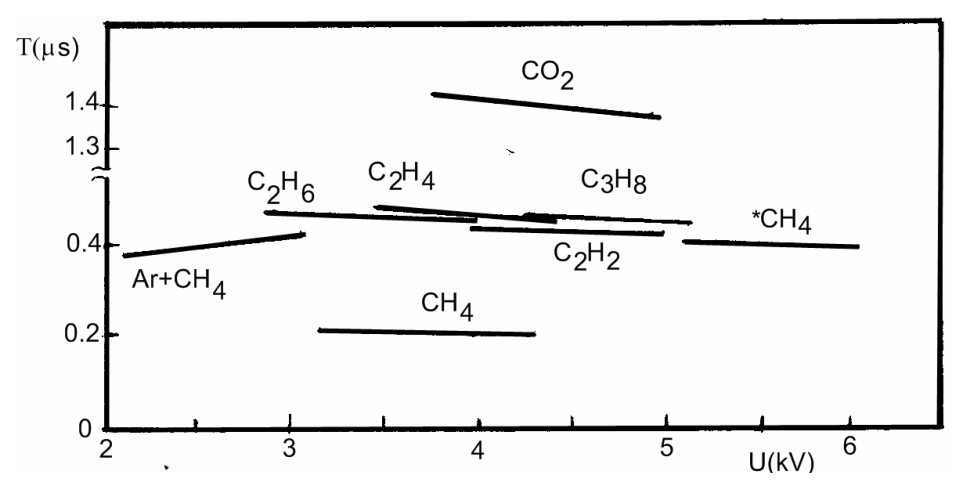

Figure 5 Transit time of electrons in carbon gases in the proportional counter with a cathode diameter of $46 \mathrm{~mm}$ and an anode diameter of $50 \mu \mathrm{m}$. (Note: ${ }^{*} \mathrm{CH}_{4}$ values are for the counter with $92 \mathrm{~mm}$ diameter; after Povinec 1979.)

However, other gases, such as $\mathrm{CH}_{4}, \mathrm{C}_{2} \mathrm{H}_{2}$, and $\mathrm{C}_{2} \mathrm{H}_{6}$, have much better and stable counting characteristics, and the 2 latter cases also have the advantage that 2 carbon atoms can be incorporated into 1 gas molecule, thus doubling the sensitivity of the counting system. Methane has been used in several laboratories (e.g. Burke and Meinschein 1955; Lal 1965; Povinec 1972b; Srdoč et al. 1983). ${ }^{14} \mathrm{C}$ results obtained by the Suess and Oeschger laboratories were based on acetylene counting (Suess 1954, 1965; Oeschger 1963).

\section{Pulse Analysis}

As the maximum energy of beta-electrons emitted by decaying ${ }^{14} \mathrm{C}$ nuclei is only $156 \mathrm{keV}$, there is room for decreasing the counter background by discriminating pulses either by amplitude and/or pulse shape (Davis et al. 1968; Povinec 1981; Curie et al. 1983). This is possible either by a multichannel analyzer for pulse-amplitude evaluation, or by a time-amplitude analysis. Such a registration system has also an advantage in simultaneous registration of pulses from a sample and background, which could help in discriminating false pulses originating either in various electromagnetic 
disturbances, or by sudden changes in cosmic-ray intensity (the Forbush decreases). As in ${ }^{14} \mathrm{C}$ analyses (the counting times are typically over a few days), such background monitoring is useful. Recently developed digital multichannel analyzers have even better characteristics for such longterm measurements.

\section{Background of Proportional Counters}

The most comprehensive study of background of proportional counters used in ${ }^{14} \mathrm{C}$ measurements (Mook 1983) showed that only a few laboratories had achieved a low background, close to the expected one (Figure 6). An inner lead shield between the central and the guard detectors (at least of $4 \mathrm{~cm}$ thickness) used in thick wall detectors decreased the counter background due to the absorption of gamma-rays (Nydal et al. 1977). An anti-neutron shield made of light material (e.g. paraffin) was also necessary, if a low background to be achieved (de Vries 1956). However, the lowest counter background was obtained using Oeschger type counters operated underground $(0.2 \mathrm{cpm} / \mathrm{L})$. A radionuclide contamination of construction materials of detectors, as well as of surrounding materials $\left({ }^{40} \mathrm{~K}, \mathrm{U}\right.$, and $\mathrm{Th}$ and their decay products), and the surrounding air $\left({ }^{222} \mathrm{Rn}\right.$ and its decay products), plus an insufficient shielding against cosmic muons have been responsible for higher backgrounds of some ${ }^{14} \mathrm{C}$ gas counters.

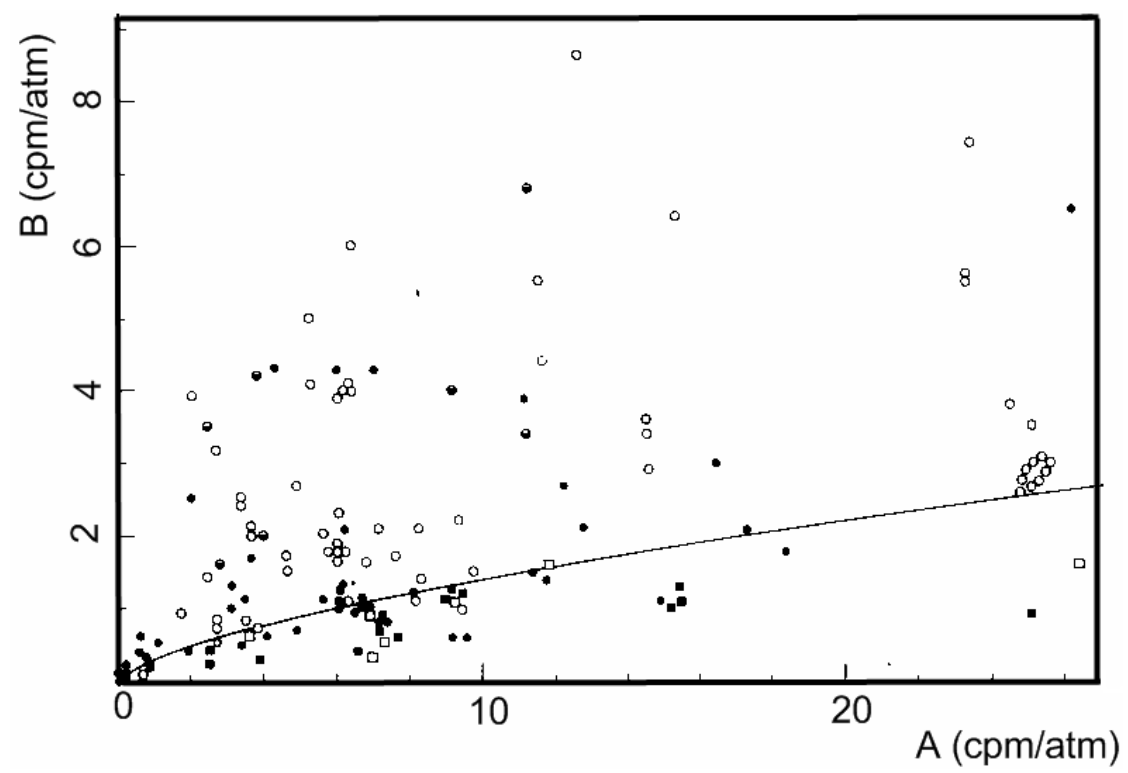

Figure 6 Normalized counter background to 1 atm and the effective counter size (represented by the normalized standard activity A). Circles represent surface and squares underground laboratories (filled symbols show laboratories with anti-neutron shielding). The solid line indicates a favorable trend $\mathrm{B}=0.3 \mathrm{~A}^{2 / 3}$ (after Mook 1983).

Further reduction in the proportional counter background can be reached by placing the detector in an underground laboratory (Loosli et al. 1986). Even a 10-m w.e. overburden can decrease the flux of secondary cosmic ray particles such as nucleons and gamma-rays by about 4 orders of magnitude (Povinec et al. 2008). Figure 6 shows that counters placed in underground laboratories have the lowest background, even at high counter volumes and/or gas pressures. However, as the hard muon component of cosmic rays at such depths decreases only negligibly, operation of detectors at deeper underground laboratories would further increase the counting sensitivity. 
A simple single-wire inner counter can be replaced by a system of cells, thus forming a multi-element detector. Such a detection system can be used for tracking beta-electrons from ${ }^{14} \mathrm{C}$ decays inside the detector. An even more sophisticated high-spatial-resolution time projection chamber (possibly inserted into a magnetic field) can be constructed for tracking single beta electrons from ${ }^{14} \mathrm{C}$ decays (Povinec 1980). However, these techniques would again require large sample volumes.

Another possibility of increasing the sensitivity of analysis would be ${ }^{14} \mathrm{C}$ enrichment using a thermal diffusion system (e.g. Grootes 1997), similar to what was done by Libby in his first trials of environmental ${ }^{14} \mathrm{C}$ measurements (Anderson et al. 1947). However, problems with contamination of old samples (with ages over 50,000 yr) and requirements for large sample volumes did not allow for wide use of this technique. With the successful developments of AMS, new ${ }^{14} \mathrm{C}$ installations have been dominated by this technique, which further opened new applications in natural and biomedical sciences.

\section{Liquid Scintillation Counters}

\section{Scintillation Cocktail}

Development of liquid scintillation counting started in 1950 (Reynolds et al. 1950), and specifically for ${ }^{14} \mathrm{C}$ in 1954 (Arnold 1954), almost simultaneously with gas counting techniques. It was natural that the first system was developed in the Libby laboratory (Arnold 1954). The scintillation cocktail usually consists of an activator (a soluble scintillator, e.g. PPO); a secondary scintillator (e.g. POPOP), which shifts the light emission spectrum of the scintillator to the maximum sensitivity of the photomultiplier; and an organic solvent prepared from a sample. It took almost $10 \mathrm{yr}$ until an optimum solvent (benzene) was mastered (Starik et al. 1961; Tamers et al. 1961; Noakes et al. 1963; Tamers 1965; Tamers and Pearson 1965), as original trials were based on ethanol and hexaneoctane (Arnold 1954), toluene (Pringle et al. 1955), methanol (Pringle et al. 1955), trimethylborate (Pringle et al. 1957), acetylene in toluene (Audric and Long 1954), liquid $\mathrm{CO}_{2}$ in toluene (Barendsen 1957), etc. The benzene solvent has the advantage that it contains $92 \%$ of carbon, has excellent scintillation properties, is stable, and can be produced entirely from the sample carbon. Its preparation is based on trimerization of acetylene, and it found large applications when high-yield chromium and vanadium catalysts were developed (Starik et al. 1963; Noakes et al. 1965).

\section{Liquid Scintillation Detectors and Electronics}

As in the case of gas detectors with anticosmic shielding, an important breakthrough in liquid scintillation counting was the use of coincidence electronics. A simple system based on a connection of a photomultiplier with a scintillation vial has several disadvantages because of thermal noise produced in the photomultiplier, and due to radioactive contamination of photomultiplier window. The operation of the liquid scintillation detector considerably improved when 2 photomultipliers were used to view the scintillation vial, both connected to a coincidence unit, which registers only light pulses originating in the scintillator within a resolution time of the coincidence unit (Bell and Hayes 1958; Laney 1971). As the response time of organic scintillators is very short, the resolution time can be also short (usually around $10 \mathrm{~ns}$ ), which helps to decrease the detector background.

Although the scintillator volume (due to high concentration of carbon in the sample, e.g. $\mathrm{C}_{6} \mathrm{H}_{6}$ vs. $\mathrm{CO}_{2}$ ) has decreased to $0.1-10 \mathrm{~mL}$ only (instead of around $1 \mathrm{~L}$ in the case of gas counting), there was still room for further background reduction either by an anticoincidence shielding of the scintillator (Noakes et al. 1973) against the hard component of secondary cosmic rays (the scintillation vial has already been shielded against soft cosmic rays and surrounding radioactive materials by $5-10 \mathrm{~cm}$ layer of lead), or by pulse discrimination. The anticosmic shielding made of a plastic scintillator has 
been incorporated, for example, into a Quantulus liquid scintillation spectrometer (Polach et al. 1988).

Further background reduction can be achieved by discriminating pulses with higher amplitudes than observed in the measured ${ }^{14} \mathrm{C}$ spectrum (similar to what has been described for gas counters), the detection system works therefore as an energy spectrometer capable of discriminating pulses originating above the ${ }^{14} \mathrm{C}$ spectrum, and simultaneously monitoring the detector background (Povinec 1981). Another way to decrease the detector background is pulse-shape discrimination (Brooks 1958), as pulses from low-energy beta-rays are shorter than from a higher-energy radiation. Thus, for small counting vials $(0.3-3 \mathrm{~mL})$ made of a clean material (e.g. Teflon or silica), background below $0.1 \mathrm{cpm}$ and ${ }^{14} \mathrm{C}$ efficiency $70-90 \%$ has been obtained (Hogg et al. 1991; Kalin et al. 1991). These were great achievements when compared to the original values obtained in the late 1950s with $10 \%{ }^{14} \mathrm{C}$ efficiency and $60 \mathrm{cpm}$ background (Horrocks 1974). A considerable decrease in the detector background (at least by a factor of 2), especially for $>10-\mathrm{mL}$ vial volumes has been achieved by operation of liquid scintillation spectrometers either in shallow (Long and Kalin 1992) or deep (Plastino and Kaihola 2006) underground laboratories.

An important advantage of liquid scintillation spectrometers (especially when they are placed in a remote laboratory) is their operation in an automatic mode, which does not require any surveillance. Thanks to the development of the high-efficiency benzene scintillation cocktail, and application of state-of-the-art electronics, the sensitivity and stability of liquid scintillation spectrometers have been comparable to proportional gas counters, and they have been successfully applied in ${ }^{14} \mathrm{C}$ studies (e.g. Burchuladze et al. 1980; Polach et al. 1988; Long and Kalin 1992), including high-precision measurements for developing ${ }^{14} \mathrm{C}$ calibration curves (e.g. Pearson 1979; McCormac 1992).

However, as in the case of gas counting, after the successful developments of AMS technologies, there has been a clear shift to AMS, which also opened up new ${ }^{14} \mathrm{C}$ applications, especially in sciences requiring submilligram samples.

There have also been large-scale applications of liquid scintillation detectors in cutting-edge science, e.g. in particle or cosmic-ray physics. The largest liquid scintillation detector recently constructed is the Borexino detector (Arpesella et al. 2008) located in the Gran Sasso underground laboratory ( $3500 \mathrm{~m}$ w.e.). The Borexino experiment aims to measure low-energy solar neutrinos in real time by elastic neutrino-electron scattering. The detector uses $300 \mathrm{t}$ (fiducial volume $100 \mathrm{t}$ ) of Pseudocumene (1,2,4-trimethylbenzene) liquid scintillator to detect the scattered electrons. As a presence of ${ }^{14} \mathrm{C}$ in the liquid scintillator is of crucial importance for obtaining extremely low background, it was necessary to measure the ${ }^{14} \mathrm{C} / \mathrm{C}$ ratio down to $\sim 10^{-18}$, the lowest ratio ever measured (we remain that the natural ${ }^{14} \mathrm{C} / \mathrm{C}$ ratio is $\sim 10^{-12}$ ). Such a sensitivity can be obtained presently only by AMS.

\section{RADIOCARBON DATING AND ACCELERATOR MASS SPECTROMETRY}

During the 12th Nobel Symposium on Radiocarbon Variations and Absolute Chronology (Olsson 1970), a suggestion was made again that counting the atoms by mass spectrometry would be quicker and more efficient, as had already been mentioned at the very beginning of the development of ${ }^{14} \mathrm{C}$ dating by Zacharias to Libby (as cited by Arnold 1987). However, the ion counting method was developed only after $30 \mathrm{yr}$ of ${ }^{14} \mathrm{C}$ research, when finally the negative ion method was shown to be possible in 1977 using equipment developed for nuclear physics.

The long half-life of ${ }^{14} \mathrm{C}$ implies that the number of atoms of the isotope ${ }^{14} \mathrm{C}$ in a contemporary sample is very large, about $6 \times 10^{10}$ per gram. This number is needed to support the beta-ray counting 
rate of $15 \mathrm{dpm}$, and so, to reach a counting accuracy of $\pm 1 \%$, or $\pm 80 \mathrm{yr}$, requires a beta-ray counting time of about $10 \mathrm{hr}$ for a gram of carbon. However, a $16-\mu \mathrm{A}$ ion source current of ${ }^{12} \mathrm{C}$ ions implies $\mathrm{a}^{14} \mathrm{C}$ ion counting rate for modern carbon of $\sim 120$ ions per second from only a 1-mg sample of contemporary carbon. The nature and significance of such a revolutionary development has been described well by Stuiver (1978). Unfortunately, ${ }^{14} \mathrm{C}$ dating by atom counting was technically difficult, but bold attempts were made nevertheless. In the meantime, ${ }^{14} \mathrm{C}$ dating by beta-ray counting flourished as a result of the ingenuity of the many researchers who followed the lead of Libby and his colleagues (e.g. Olsson 1970; Berger and Suess 1979).

\section{Origins of ${ }^{14} \mathrm{C}$ lon Counting by AMS}

In the 1930s, Rutherford and others first created the isobars tritium $\left({ }^{3} \mathrm{H}\right)$ and ${ }^{3} \mathrm{He}$, by bombarding deuterium with deuterons (Oliphant et al. 1934). They concluded from their measurements that tritium was the stable isotope, but then failed to detect it in nature by mass spectrometry. The very low abundance of ${ }^{3} \mathrm{H}^{+}$was hard to detect by mass spectrometry because of the high abundance of the $\mathrm{HD}^{+}$and $\mathrm{H}_{3}{ }^{+}$molecular ions (Rutherford 1937). During 1939, Alvarez (1981), in a response to this failure, conceived the idea of using a cyclotron to detect such rare isotopes. Some of the basic principles of what later became known as AMS were clearly stated at that time. They were that the highenergy ions, accelerated by the cyclotron, could be separated completely as ${ }^{3} \mathrm{H}^{+}$and ${ }^{3} \mathrm{He}^{++}$ions. In addition, the final rare ions could also be identified and counted by the methods of nuclear physics. Alvarez and Cornog $(1939 \mathrm{a}, \mathrm{b})$ then went on to prove conclusively, using a nuclear reaction, that the rare ions they were detecting in helium gas were indeed due to the ${ }^{3} \mathrm{He}$ isotope, which was present naturally at sub-parts per million of ${ }^{4} \mathrm{He}$. The radioactive isotope ${ }^{3} \mathrm{H}$ is also present but hard to detect by mass spectrometry. The idea of separating the atomic isobars ${ }^{3} \mathrm{H}$ and ${ }^{3} \mathrm{He}$, and the molecular isobars as well, at higher energies by using an accelerator was born with the Alvarez suggestion. The separation of ${ }^{14} \mathrm{~N}$ and ${ }^{14} \mathrm{C}$ ions by the greater range in matter of ${ }^{14} \mathrm{C}$ was implicit in the early work with the cyclotron. Also, removal of the molecular interferences could in principle be accomplished by the resonant acceleration of the ions in the cyclotron. Consequently, the atomic ion counting method for ${ }^{14} \mathrm{C}$ at high energy was available even before the discovery of ${ }^{14} \mathrm{C}$ dating, but this was technically a very difficult task. The ion source memory effect would have had to be solved, for example. The proposal by Muller (1977) to actually use a cyclotron for ${ }^{14} \mathrm{C}$ dating was not made until 1977 after extensive development work on accelerators, ion sources, and sensitive detection methods. The maturity of nuclear physics was then also generating imaginative ways to look for free quarks (Muller et al. 1977; Stephenson et al. 1977), super heavy elements (Schwartzschild et al. 1977), and other trace entities suggested by the developments in the physics of the nucleon and nucleus. In 1977, the beta-ray counting method was state of the art and the time was clearly right for further attempts to measure ${ }^{14} \mathrm{C}$ by ion counting at higher energies, so that smaller as well as older samples could be analyzed more quickly.

\section{The First Attempts to Use lon Counting for Radiocarbon Dating}

The original beta-ray counting method used by Libby rapidly developed and by 1977 had become a precise if demanding tool (Olsson 1970; Berger and Suess 1979) for dating in archaeology and geophysics. The ion counting idea for ${ }^{14} \mathrm{C}$ was, however, not forgotten ${ }^{4}$ and an imaginative new approach by Anbar (1975) and Schnitzer et al. (1975) started in the early 1970s, which culminated in a determined attempt to detect ${ }^{14} \mathrm{C}$ at natural abundances by mass spectrometry. The idea was to

${ }^{4} \mathrm{H}$ Oeschger, J Houtermans, H Loosli, and M Wahlen - comments on p 471-98 in Olsson (1970); and by H W Wilson on p 238 in Berger and Suess (1979). 
remove the ${ }^{14} \mathrm{~N}$ ion from interfering with the ${ }^{14} \mathrm{C}$ ion detection not by using high energy but by eliminating the $\mathrm{N}$ ions at the ion source, exploiting the supposedly well-known inability of $\mathrm{N}$ or $\mathrm{N}_{2}$ to form negative ions. Then, mass spectrometry using $\mathrm{C}_{\text {or }} \mathrm{CN}^{-}$ions was postulated to be a possibility.

Ion sources for generating large $\mathrm{C}$ ion beams became available in 1959 as a result of the development of the tandem electrostatic accelerator for nuclear physics. This development was also stimulated by Alvarez (1951) after the device was invented in the 1930s by Bennett (1940) and Kallmann and Kuhn (1940). The drawing in the latter patent application looks very much like a modern compact vacuum-insulated tandem for ${ }^{14} \mathrm{C}$ dating! Such negative ion sources were initially rather complicated as they required the charge changing of $\mathrm{C}^{+}$ions into negative ions by first accelerating them to a $25-\mathrm{kV}$ electrode, and then passing them though a suitable gas, where several collisions resulted in a fraction of the $\mathrm{C}^{+}$ions becoming $\mathrm{C}$ ions (Weinman and Cameron 1956). The many $\mu \mathrm{A}$ of negative ions, now at $50 \mathrm{keV}$ after what was also tandem acceleration, were then suitable for injecting into the ion optics of the long high gradient, $\sim 1 \mathrm{MV} / \mathrm{m}$, acceleration tubes of the new large tandem electrostatic accelerators (Bromley 1974; Hellborg 2005). These negative ions were then accelerated towards a high-voltage electrode at about $5 \mathrm{MV}$, where they were changed by gas stripping into positive ions for further acceleration in order to have both the energy and ion current suitable for studying nuclear reactions. Such negative ion sources were soon known to have large memory effects, as well as also producing no detectable $\mathrm{N}$ ions (Kuehner et al. 1960; Litherland 1962).

A simpler ion source was chosen by Anbar $(1975,1978)$, and Aberth and Peterson (1967), as it was known that the $\mathrm{CN}$ ion had a high electron binding energy and could be made directly in the ion source using an admixture of $\mathrm{CO}_{2}$ and $\mathrm{N}_{2}$ gases. Unfortunately, unlike the $\mathrm{N}$ ion, the $\mathrm{N}_{2}$ ion was later found to be metastable. This was shown much later (Gnaser 1997; Middleton and Klein 1999) when the ion was first discovered. This pioneering work in ${ }^{14} \mathrm{C}$ dating by atom counting was discontinued in mid-1975 after almost reaching the level of natural ${ }^{14} \mathrm{C}$ (Anbar 1978). The problem was identified then as being due to the interfering ${ }^{29} \mathrm{Si}^{-}$isotope. This problem would have been quickly solved if the $\mathrm{CN}$ ions had been injected into a tandem accelerator and identified at higher energy using the principles stated by Alvarez in 1939. Here, it should be emphasized that it would not have been a simple change, as the $\mathrm{CN}$ ions would also have had to be accelerated to about 40 to $50 \mathrm{keV}$ in order to be accepted efficiently by the tandem accelerator. The additional problem of ion source memory, which was almost certainly present, was not studied in this pioneering work. Unfortunately, the pioneering work by the chemists using $\mathrm{CN}$ for isobar separation, in the early 1970s, was unknown to the nuclear physicists, whose work was focused on high-current ion source developments for nuclear physics.

\section{The $\mathrm{Cs}^{+}$Sputter lon Source Development}

The ion current and memory problem was solved, however, by the contemporary development of the $\mathrm{Cs}^{+}$sputter ion source for nuclear physics, after a conference in 1972 (Chapman 1972). The ion source that was later to be used extensively for ${ }^{14} \mathrm{C}$ measurements was developed as a result of the need for a negative ion source that could generate many $\mu \mathrm{A}$ of heavy atomic ions such as $\mathrm{C}, \mathrm{Ca}$, and all elements up to uranium for studies in nuclear structure. Here, it is worth noting that atomic negative ions usually have rather low binding energies and are consequently not easy to make in quantity. Previously, gas ion sources dominated the scene, but they were not flexible enough for the nuclear physics requirements and had long memories of the previous samples used in the ion source. The long memories were no more than a nuisance for nuclear physics, although once the carbon memory effect produced a ${ }^{12} \mathrm{C}$ ion beam suitable for nuclear physics studies and so hastened the discovery of rotational bands in the nucleus ${ }^{20} \mathrm{Ne}$ (Litherland et al. 1961). The cesium ion sputter sources, however, used solid samples with low-work function surfaces, which are suitable for gen- 
erating large ion currents of low-electron affinity atoms, and it was found possible to make an almost universal ion source (Middleton and Adams 1974) by simply changing the elements used in the ion source targets. The attractive feature for ${ }^{14} \mathrm{C}$ dating by ion counting was the expected low level of ion source memory of previous samples due to the use of solid carbon samples, as well as the high $\mathrm{C}$ ion current and the potential for using several ${ }^{14} \mathrm{C}$ samples in rapid succession.

\section{The Remarkable Year of AMS 1977}

In 1977, several developments were converging on solutions to the atom counting problem of ${ }^{14} \mathrm{C}$ for ${ }^{14} \mathrm{C}$ dating. The cyclotron was revived by Alvarez as a mass spectrometer during a search for integrally charged quarks (Muller et al. 1977) and, as a result of that experience, Muller (1977) proposed the use of a cyclotron for ${ }^{14} \mathrm{C}$ dating. At about the same time, the mass spectrometry problem was again being approached with a suggestion (Hall et al. 1978) for laser isotope enrichment of ${ }^{14} \mathrm{C}$ to overcome some of the problems of the very small ${ }^{14} \mathrm{C} / \mathrm{C}$ ratio in natural samples. Isotope enrichment benefits the beta-ray counting method too, as was found at the beginning of the ${ }^{14} \mathrm{C}$ development (Anderson et al. 1947). In addition, the tandem accelerator had been proposed (Purser 1977) for mass spectrometry to reach very low abundance levels of stable isotopes by molecular dissociation during high-voltage charge changing. The problem of the degree of instability of the $\mathrm{N}$ was again being considered because the elimination of the huge flux of ${ }^{14} \mathrm{~N}$ ions at the ion source was considered to be the best way to attack the difficulty of eliminating them, and the new sputter ion source was just beginning to be used on nuclear physics tandem accelerators.

It is then maybe not surprising that tests with the new $\mathrm{Cs}^{+}$sputter ion sources quickly demonstrated that the ${ }^{14} \mathrm{~N}$ ions did not interfere with the detection of ${ }^{14} \mathrm{C}$ ions at natural levels, and that consequently, quite a small tandem accelerator could be used to remove the molecular ions present for ${ }^{14} \mathrm{C}$ dating. The surprising result was that the background was so low (Purser et al. 1977). The very first results showed that the background from a tandem accelerator system, helped by the natural level of instability of $\mathrm{N}$, could be as low as about ${ }^{14} \mathrm{C} / \mathrm{C} \sim 10^{-15}$, corresponding to about $60,000 \mathrm{yr}$ in dating. The low level of $14 \mathrm{~N}$ anions was rapidly confirmed (Nelson et al. 1977). It was a relief to realize that quite small accelerators could be used and that the higher energies used originally by Alvarez were not necessary for ${ }^{14} \mathrm{C}$ dating if negative ions were used. As a result of the early work, small $3 \mathrm{MV}$ tandems were designed specifically for ${ }^{14} \mathrm{C}$ dating (Purser and Handley 1978) and many nuclear physics tandems were adapted for such measurements (Nelson et al. 1977); a partial list up to 1984 is available (Litherland 1984).

As described by Gove (1999) in his book From Hiroshima to the Ice Man, the early days of AMS included tests to see how well cyclotrons and tandems could measure ${ }^{14} \mathrm{C}$ in natural samples. For ${ }^{14} \mathrm{C}$ dating, the tandem came out on top due partly to the simpler operation of the tandem and partly due to the use of negative ions. However, subsequent attempts to extend the measurements to some of the longer-lived isotopes such as ${ }^{10} \mathrm{Be},{ }^{36} \mathrm{Cl}$, and ${ }^{99} \mathrm{Tc}$ (Fifield 2000) demonstrated that high energy was exceedingly useful when the interferences could not be resolved at the ion source. For about 30 $\mathrm{yr}$, several important isotopes have had to be analyzed at the highest possible ion energies in order to separate the isobars, and certainly ${ }^{36} \mathrm{Cl}$ was one of them, although even that isotope proved to be difficult for cyclotrons too.

The ease with which a tandem accelerator could be used for ${ }^{14} \mathrm{C}$ dating and the difficulties encountered with positive ions and large cyclotrons (Muller 1978) resulted in the proposal (Muller et al. 1981; Bertsche et al. 1990) for small 50-keV cyclotrons exploiting negative ions. These machines were then successfully developed (Chen et al. 2000). However, when it was necessary to detect rare atoms like ${ }^{39} \mathrm{Ar}$ and ${ }^{81} \mathrm{Kr}$ in nature (Collon et al. 2000), the cyclotron has so far proved to be superior 
using positive ions, as such atoms make negative ions with difficulty. They must also be accelerated as positive ions to such a high energy that they can be completely stripped of all their electrons for certain identification. It is still true that higher energies are very useful for the general mass spectrometry of long-lived radioactive isotopes. However, even the largest accelerators were found (Henning 1987) to be insufficient for separating the heavier isobars ${ }^{205} \mathrm{~Pb}$ and ${ }^{205} \mathrm{Tl}$, even at $2 \mathrm{GeV}$ ion energy.

\section{Radiocarbon Dating by Ion Counting: The Learning Phase}

Some of the early work (Litherland 1978) was specifically directed towards the design of a compact tandem system for ${ }^{14} \mathrm{C}$ dating, and while these machines were being constructed several tandems previously engaged entirely in nuclear physics research were quickly adapted for dating. Several modifications were added such as electric analyzers to specify the ion energy before (Kilius et al. 1987) and after (Elmore et al. 1984) tandem acceleration. This reduced the background in the final ion detector due to charge-changing collisions in the tandem acceleration tubes. However, it took some time to put it in adequate electric analysis, and in the meantime there was found to be a definite need to use the high-energy particle detection techniques to clean up the particle spectrum. Then, it was found empirically that the extra information provided by the high-energy analysis was useful and that ion identification added confidence to the isotope ratio measurements, which were unfamiliar to most nuclear physicists. Much early data was taken with some degree of pulse-height analysis to compensate for inadequate electric and magnetic filtering.

The measurement of the carbon isotope ratios was first done in rapid sequence and the first attempt to measure the ${ }^{13} \mathrm{C}$ and ${ }^{14} \mathrm{C}$ isotopes simultaneously was made (Southon et al. 1990). Later, improved ion optical devices (Litherland and Kilius 1990) were employed. These in turn became more difficult to use by the steady improvements in the ion currents of ${ }^{12} \mathrm{C}$. Currents as high as $8 \mathrm{~mA}$ of ${ }^{12} \mathrm{C}$ anion have been reported (Ishikawa 1995) and it is probably true to say that accurate dating with such ion currents will be a challenge. It is likely that dating will become progressively more difficult in the future using simultaneous measurements on the isotopes because of the power requirements of even small tandems. Even if such high-current ${ }^{14} \mathrm{C}$ dating AMS were undertaken, the understanding and control of the effects of space charge will create new problems. The alternative of rapid pulsing may be more adaptable to ${ }^{14} \mathrm{C}$ dating by AMS in the future, as the ${ }^{12} \mathrm{C}^{-}$ion currents continue to rise due to ion source developments.

\section{Accuracy of Radiocarbon Dating by AMS}

The early years of ${ }^{14} \mathrm{C}$ dating with tandem accelerators were a learning experience for all concerned, as much of the equipment that was used had to be modified for isotope ratio measurements in a range of ratios previously unexplored (Bennett et al. 1978). A particularly difficult problem encountered at the beginning was the creation of graphite targets for the sputter ion sources as these empirically gave the largest ion currents. The cracking of acetylene was an early contender for the recommended method, but it was replaced after the first decade of research by the now standard catalytic cracking method introduced at McMaster University (Vogel et al. 1987). This method matched much better the rapid development of the early porous frit-based sputter ion sources to ones with a solid hemispherical ionizer. One of these newer ion sources was later to give the largest negative ion current of some 250 to $325 \mu \mathrm{A}$ (Fallon et al. 2007) at an AMS laboratory. These developments are continuing and the exploitation of such large ion currents, especially at elevated energies, requires experience. There is a strong indication that the higher efficiency for ${ }^{14} \mathrm{C}$ obtained at the higher currents is partly attributable to space charge-assisted extraction (Asi 2001). This is a new dimension to the problem that will require study in future. 
The isotope ratios of ${ }^{12} \mathrm{C}:{ }^{13} \mathrm{C}:{ }^{14} \mathrm{C}$ are all needed for a complete ${ }^{14} \mathrm{C}$ measurement, because of the isotope fractionation occurs at many places in an AMS system. The emitted ion ratios from a sputter target show pronounced sputter fractionation (Gnaser 2008), which can be corrected appropriately by comparing the unknown rapidly and frequently with a standard such as oxalic acid I or II and more recently ANU sucrose as a standard. Fractionation also occurs in the stripping of the anions in the tandem, but again, by rapid intercomparisons with standards, this problem can be corrected and in general it is found that the stability of the tandem accelerator and its subsystems is quite adequate. For some time, the rapid pulsing method (Suter et al. 1984) competed with an attempt to measure the isotope ratios simultaneously (Litherland and Kilius 1990; Southon et al. 1990). Initially, only ${ }^{13} \mathrm{C}$ and ${ }^{14} \mathrm{C}$ were measured simultaneously and later for the World Ocean Circulation Experiment (WOCE), discussed below, all isotopes were intended to be put through the tandem simultaneously to attain the highest accuracy. Unfortunately, simultaneous injection methods are really best suited for measurements of stable isotopes, and the huge abundance difference between ${ }^{14} \mathrm{C}$ and the stable isotope ${ }^{12} \mathrm{C}$ of over $10^{12}$ was found to be difficult to use. Thus, the intense isotopic beam was rapidly chopped mechanically to $1 \%$ of the time and the rare isotope counted during the $99 \%$ of the time when the intense pulses were not present. This reduces the background but removes partly the advantage of simultaneous measurement. It was found that the ${ }^{13} \mathrm{C}$ and ${ }^{14} \mathrm{C}$ could be counted simultaneously at modest $30-\mu \mathrm{A}{ }^{12} \mathrm{C}$ negative ion currents, but the method of rapid pulsing now seems to be becoming more common as the ion currents can then be increased still further-although new problems will undoubtedly arise to be solved in their turn.

The early comparisons between beta-ray measurements and those from AMS (Bennett et al. 1978) were in general satisfactory. After experience was gained, the agreement between the blind measurements between AMS using tandems and the best beta-ray counting systems were indeed excellent as shown in Table 1 (Beukens 1992). These measurements were followed by the very large study in connection with the WOCE. This is an impressive study discussed later and demonstrates an overall reproducibility of better than $\pm 0.4 \%$ for many thousands of samples. The early blind tests using a tandem given in Table 1 were a little more reproducible than that, but were only for a few samples that received special treatment. The overall picture is one of results that are comparable between laboratories using beta-ray counting and ion counting, with ion counting requiring much smaller samples, which was an essential feature of the use of AMS for WOCE. The collection for beta-counting of barrels of seawater at various depths was replaced by $500-\mathrm{mL}$ bottles for AMS. A future study of the dispersal of the natural and human created ${ }^{14} \mathrm{C}$ may require a shipboard ${ }^{14} \mathrm{C}$ dating device with high throughput capability. These devices may not use AMS ion counting methods.

Table 1 Comparison of ${ }^{14} \mathrm{C}$ results obtained by beta counting and AMS.

\begin{tabular}{ll}
\hline $\begin{array}{l}\text { Quaternary Research Center, } \\
\text { University of Washington } \\
\text { (yr BP) }\end{array}$ & $\begin{array}{l}\text { IsoTrace Laboratory, } \\
\text { University of Toronto } \\
\text { (yr BP) }\end{array}$ \\
\hline $4132 \pm 18$ & $4157 \pm 21$ \\
$6973 \pm 20$ & $7019 \pm 20$ \\
$\geq 55,000$ & $53,100 \pm 600$ \\
\hline
\end{tabular}

Although the accuracy of beta-ray and ion counting can be similar for samples $<10,000 \mathrm{yr}$ old, the situation becomes quite different when older samples are analyzed as is shown in Table 1. Finite ages are often recorded for samples well over $50,000{ }^{14} \mathrm{C}$ yr old, using AMS, but as there are no calibration data for such ${ }^{14} \mathrm{C}$ dating extending securely that far back in time, the meaning of such measurements is still open to discussion. Measurements are being carried out to extend the calibration data (Stuiver and van der Plicht 1998) so that the older dates can be put into a proper context. Inter- 
laboratory comparisons are now carried out extensively and the analyses published in Radiocarbon (Scott 2003). The enormity of this task is matched by the importance to the ${ }^{14} \mathrm{C}$ dating community.

As an example of general-purpose AMS facilities, we present 2 typical designs, frequently used for ${ }^{14} \mathrm{C}$ research. Figures 7 and 8 show the 3MV Tandetron machine from High Voltage Engineering Europe (HVEE, the Netherlands), which is the modern general-purpose AMS machine operating at the Institute of Earth Environment, Xi' an, China. The key components of this machine are the 2 ion sources and the rotatable electric analyzer, which allows 2 different ion sources to be made available quickly, or the servicing of 1 ion source while the other is in operation (as it is essential to clean ion sources frequently to reduce the memory effect of the earlier samples). Another key component, also present at the VERA AMS facility, Vienna University (Figure 9), which has been regarded as absolutely essential, is the second high-energy magnet after the large electric analyzer, which is removing the remains of the gas scattering of the heavier elements in the first magnet. Although the Pelletron machine from National Electrostatics Corporation (NEC, USA) in Vienna is of an older design (Kutschera 2005), it has modern peripheral equipment enabling a wide range of applications in environmental, nuclear, and atomic sciences.

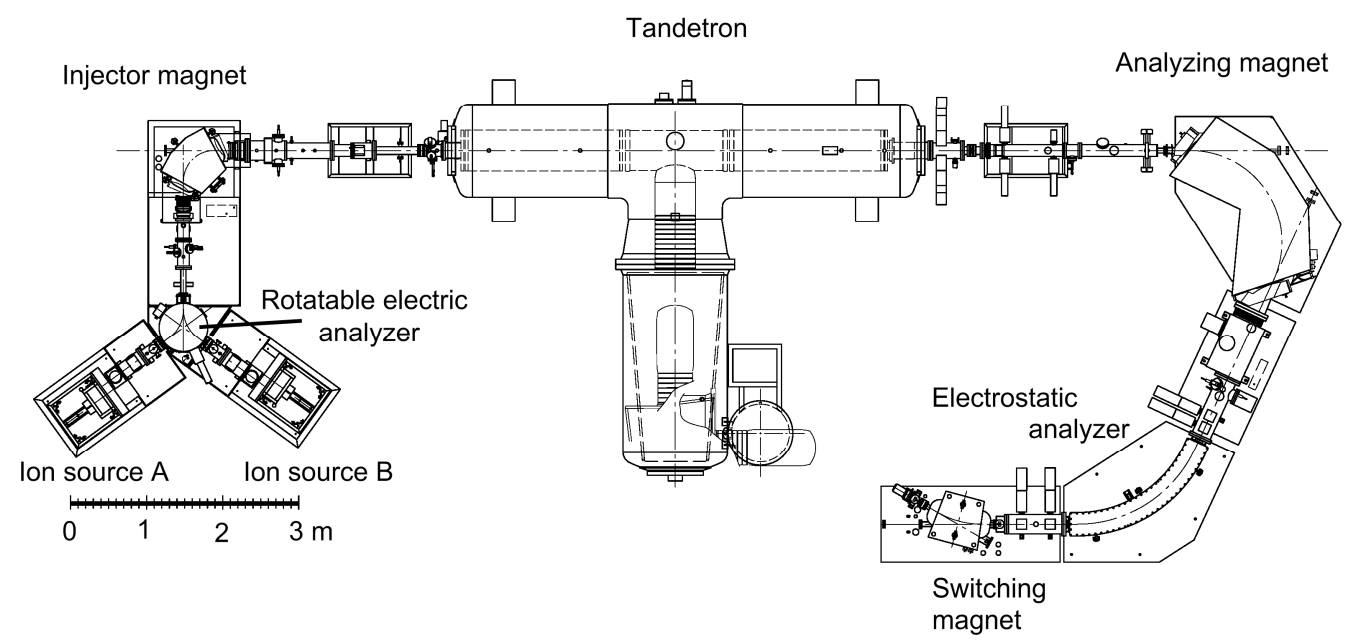

Figure 7 A schematic view of the Tandetron (High Voltage Engineering Europa, the Netherlands) general-purpose AMS facility at the Xi' an AMS Centre, China.

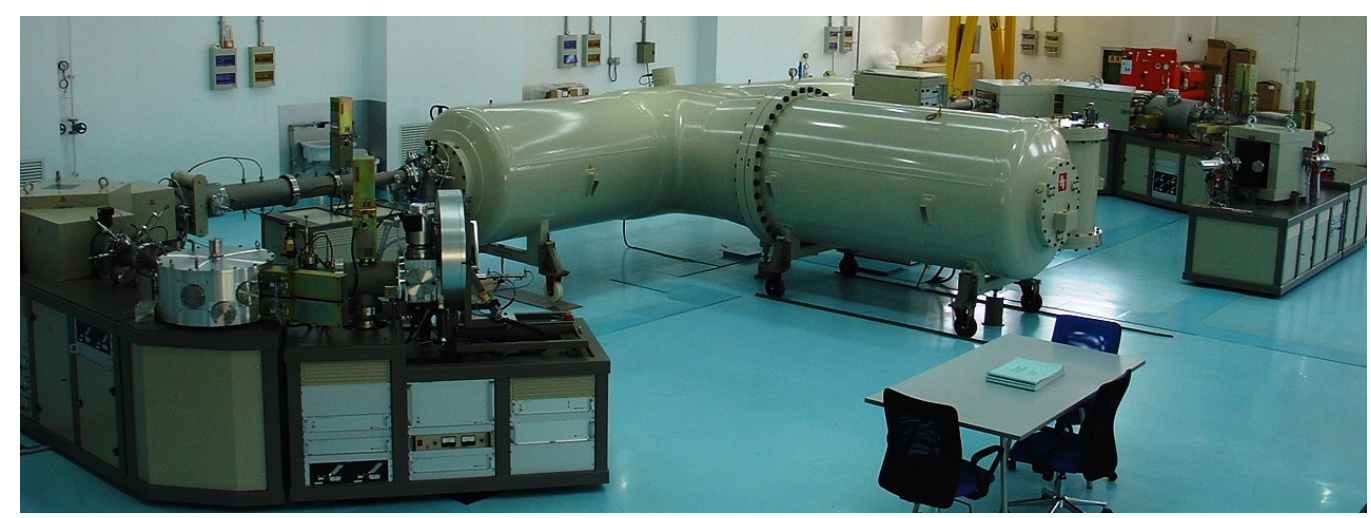

Figure 8 Photo of the Tandetron (HVEE) general-purpose AMS facility at the Xi' an AMS Centre, China 


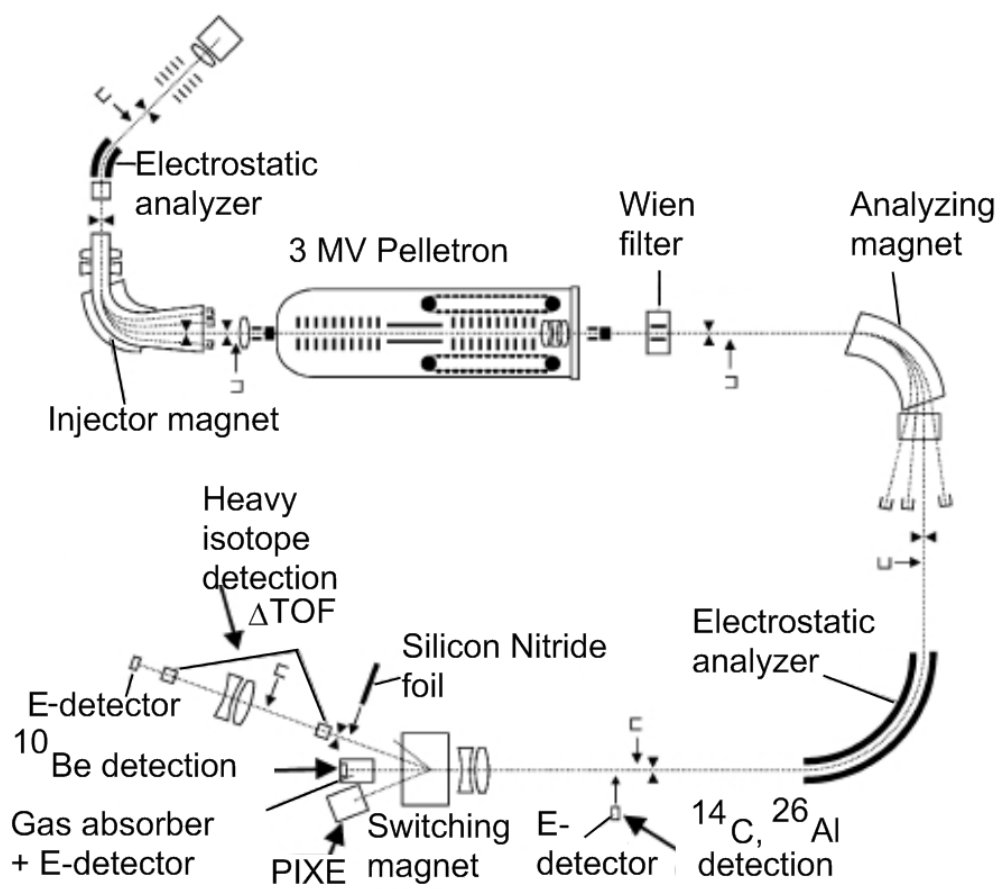

Figure 9 A schematic view of the Pelletron (National Electrostatics Corporation, USA) general AMS facility at the VERA Laboratory, University of Vienna, used for the analysis of ${ }^{14} \mathrm{C},{ }^{10} \mathrm{Be},{ }^{26} \mathrm{Al}, \mathrm{U}$, and $\mathrm{Pu}$ isotopes, PIXE, and nuclear and atomic physics studies (after Kutschera 2005).

\section{How Old is the Oldest Radiocarbon?}

In this section, the evidence that ${ }^{14} \mathrm{C}$ samples greater than $100,000{ }^{14} \mathrm{C}$ yr old exist will be presented. However, conventional beta-ray counting and AMS alone are not yet adequate to measure such samples and, in addition, their actual age is unknown, as the ${ }^{14} \mathrm{C}$ clock has to be calibrated to that period.

At a ${ }^{14} \mathrm{C} / \mathrm{C}$ ratio of less than about $10^{-18}$, evidence has been found that such samples can come from underground hydrocarbons, such as natural gas, that have been isolated from cosmic rays and uranium ores for a long time. Large organic scintillation detectors, such as the Borexino 100-ton underground test detector for solar neutrino studies, have been made from these sources as they would have to have a low beta-ray background counting rate from ${ }^{14} \mathrm{C}$. Before the construction of the Borexino detector, the level of ${ }^{14} \mathrm{C}$ in deep underground material was not known reliably, so that a series of measurements, using $100 \times$ industrially (Isotec) enriched ${ }^{13} \mathrm{C}$, was made by AMS (Beukens 1993; Beukens et al. 2004; Arpesella et al. 2008). These samples were calculated to be enriched in ${ }^{14} \mathrm{C}$ by a factor of 200 and so when the normal background of ${ }^{14} \mathrm{C}$ was observed at near $4 \times 10^{-16}$ for ${ }^{14} \mathrm{C} / \mathrm{C}$, it was concluded that the original natural gas had a ${ }^{14} \mathrm{C} / \mathrm{C}$ ratio of less than about $2 \times 10^{-18}$. The degree of enrichment of the samples in this case was obvious from the relative intensity of the ${ }^{13} \mathrm{C}$ to the ${ }^{12} \mathrm{C}$ anions generated by the ion source. The Borexino detector was later made using petroleum from deep underground and gave a ${ }^{14} \mathrm{C}$ counting rate corresponding to the same background limit, which is a remarkable coincidence (Alimonti et al. 1998). What is even more, the spectrum of pulses from the large scintillation detector gave measurement of the shape of the ${ }^{14} \mathrm{C}$ beta-spectrum at such a low level of ${ }^{14} \mathrm{C}$. The level reached is undoubtedly due to contamination of the AMS measurement, 
however, the Borexino data represents the oldest ${ }^{14} \mathrm{C}$ dates ever obtained. It is expected that in the future carbonaceous materials with ${ }^{14} \mathrm{C} / \mathrm{C}$ ratios much less than $2 \times 10^{-18}$ will be found.

Subsequently, tests showed that the background due to the AMS could be lowered arbitrarily so that the limitation of the age will be due entirely to the ${ }^{14} \mathrm{C}$ contamination of the sample. Contributions are also possible from the contamination of the residual gas of the vacuum system and the contamination of the ion source materials (Litherland et al. 2005). It is indeed remarkable that the background routinely reached at present by AMS is not very different from that obtained with the very first measurement (Purser et al. 1977). Very low background detectors must of course be constructed to extend our knowledge of the universe, and the recent successes of the Sudbury Neutrino Observatory and other underground laboratories indicate an increasing understanding of the sources of radioactive contamination. The possibility of actually constructing and operating devices completely underground, to avoid the cosmic-ray intensity at the surface of the Earth has been appreciated by ${ }^{14} \mathrm{C}$ daters for nearly $60 \mathrm{yr}$. As 50,000-ton organic scintillation counters are being considered (Marrodán Undagoitia et al. 2006), it is likely that this low-background research into materials will be continued in spite of the difficulties.

\section{The Future of AMS for Radiocarbon Dating}

Very small accelerators have been developed (Synal et al. 2000, 2007; Skog 2007) for measuring ${ }^{14} \mathrm{C}$. Voltages of $250 \mathrm{kV}$ are used to destroy the molecular anions of ${ }^{12} \mathrm{CH}_{2}$ and ${ }^{13} \mathrm{CH}$, as then repeated collisions with gas molecules destroy them so that their abundance decreases exponentially with gas pressure (Lee et al. 1984). The ${ }^{14} \mathrm{~N}$ is eliminated by the use of negative ions. The additional multiple scattering during the conversion from anions to singly charged cations is accommodated by increasing the apertures of the mass spectrometry. In addition, special counters using very thin ( $\sim 50$ $\mathrm{nm}$ ) uniform $\mathrm{Si}_{3} \mathrm{~N}_{4}$ windows and cooled preamplifiers are used. At $250 \mathrm{kV}$, it is not necessary to use a pressurized tandem and one AMS version of the small accelerator simply has the final mass spectrometry in air (Skog 2007) at that voltage. Another version (Suter et al. 2007) uses vacuum insulation for the tandem.

These small accelerators are now becoming more common for ${ }^{14} \mathrm{C}$ dating, but they can be used for other long-lived radioactive atoms (Tanner et al. 2002). How small a voltage can be used on such machines has yet to be determined as molecular anions or cations can be also destroyed at $\mathrm{eV}$ ion energies in chemical reaction cells (Bandura et al. 2006) either by chemical reactions or by collision induced dissociation (CID) at "elevated" ion energies of $\sim 100 \mathrm{eV}$. At very low energies, the detectors developed for nuclear physics become much less useful and ion identification becomes impossible by the methods initially proposed by Alvarez (1981). A partly compensating advantage is that $\mathrm{Q}=+1$ can be used and at $\sim 250 \mathrm{keV}$ the efficiency becomes near optimum; therefore, more advanced ion detectors can be used at least for the light elements (Jull et al. 2008). At higher ion energies, charge state division becomes important and that tends to reduce the ion detection efficiency, but then the specificity of the ion detection becomes greater.

Tandem accelerators with voltages of about $3 \mathrm{MV}$ seem to be a very good compromise between all the conflicting requirements for an AMS system that is capable of a wide variety of research. For example, information on the structure of the molecules used for AMS can be obtained because in several cases the molecular fragments and their add-up peaks can be recorded simultaneously in the final ionization counter. Ions that have the same E/Q and M/Q are all transmitted through the highenergy mass spectrometry and are only separated by their actual energy and their $\mathrm{dE} / \mathrm{dx}$ in the final counter. The ions ${ }^{12} \mathrm{C}^{+3}$ and ${ }^{16} \mathrm{O}^{+4}$ from the same molecule are examples. The identification of multiple fluorides (Kubik and Elmore 1989) is particularly useful. 
Positive ion sources can also be used when the higher-energy mass spectrometry is located at voltage. This variation of AMS is potentially important because positive ions as well as anions can be separated in chemical reaction cells prior to the acceleration through $250 \mathrm{kV}$. This has not yet been tried, but the potential to separate isobars using cations (Bandura et al. 2006) is probably greater than that for using anions (Litherland et al. 2007). For both anions and cations, ${ }^{14} \mathrm{C}$ dating can in principle be carried out with the help of chemical reaction cells. Laser separation of isobars of anions has also been shown to work (Berkovits et al. 1989; Lu and Wendt 2003; Forstner et al. 2008). By retarding the ions to low energies to increase the time they spend in the laser field, the dissociation of the lower binding energy isobaric anion can be used for attenuation. For specialized applications, no further acceleration for identification purposes may be needed.

\section{RADIOCARBON AND THE OCEAN SCIENCES - VIEWED FROM THE PERCH OF A DEDICATED ${ }^{14}$ C AMS FACILITY}

In the late 1980s, a Request for Proposals was issued by the National Science Foundation to establish a dedicated facility to analyze samples of marine science origin for ${ }^{14} \mathrm{C}$, using accelerator mass spectrometry. The main driver for this project was the new WOCE project that was expected to generate in excess of 13,000 seawater samples to be analyzed for dissolved inorganic carbon at such a laboratory. The Woods Hole Oceanographic Institution was awarded the project and the National Ocean Sciences Accelerator Mass Spectrometry Facility (NOSAMS) was established in 1989 under the leadership of Glenn Jones in the Department of Geology and Geophysics (Jones et al. 1990). During the past almost $20 \mathrm{yr}$, over 1100 scientific papers have been published that cite or rely on ${ }^{14} \mathrm{C}$ results produced at this facility. In some instances, other AMS laboratories may also have been involved in the measurements. This review will attempt to show how progress in the marine sciences was affected by the data that were obtained at NOSAMS and distributed to numerous researchers all over the world. Only publications that explicitly or implicitly acknowledge AMS measurements that were performed at NOSAMS are included in this review. Technical aspects of the AMS measurements will not be covered as those have been discussed extensively in the previous chapter, as well as in the proceedings of the international AMS conferences. Clearly, there will not be enough space to mention all of our "clients" research in this chapter and emphasize that this does not constitute judgment over the importance of any specific topic. There will be coverage of 4 main areas: Tracer mapping programs, Paleoresearch, Biogeochemical applications, and Future trends. The hope is that this review will give readers, who do not have time to scan the entire range of fieldspecific journals, entry points into aspects of ${ }^{14} \mathrm{C}$ research in neighboring disciplines.

\section{Large-Scale Tracer Mapping Programs, Feeding Into Ocean Circulation Models}

The original NOSAMS task, extracting dissolved inorganic carbon (DIC) from seawater samples and subsequent AMS analysis for ${ }^{14} \mathrm{C}$, has not stopped with the completion of the WOCE program (McNichol et al. 2000). We are still analyzing around 1000 samples per year for the follow-up CLIVAR (Climate Variability and Predictability) study (http://www.clivar.org.), designed to fill in some of the gaps in the prior projects and revisit sites for the assessment of time dependence of the ${ }^{14} \mathrm{C}$ concentration in the oceans. Figure 10 (von Reden et al. 1999) shows an example of the extent of the raw data set that was accumulated until the late 1990s. $\Delta^{14} \mathrm{C}$ (a measure of the offset from pre-bomb natural ${ }^{14} \mathrm{C}$ ) is shown for the upper $1200 \mathrm{~m}$ of the water column in the Pacific, Southern, and Indian oceans, reflecting the penetration of ${ }^{14} \mathrm{C}$ generated in the 1960 s by tropospheric nuclear bomb testing. The enormous task of compiling the data into formats usable in modeling and other types of interpretative assessments has been carried out by Princeton scientist Robert Key (Key 1996; Key et al. 1996, 2002, 2004). The new data set vastly expands and refines the ${ }^{14} \mathrm{C}$ maps available from prior 
programs (e.g. GEOSECS, http://ingrid.ldeo.columbia.edu/SOURCES/.GEOSECS/). Since the mid-1990s, numerous papers have been published that use the new data together with other ocean parameters to arrive at new answers to some very important questions. One very obvious question is: how much ${ }^{14} \mathrm{C}$ has been taken up by the oceans during the bomb tests? Using modeling simulations, Peacock (2004) discusses a discrepancy between assessments from the 1990s (Broecker et al. 1995; Hesshaimer et al. 1994), arriving at a number between the 2 earlier estimates for the mid$1970 \mathrm{~s}$, in the order of about $2.5 \times 10^{28}$ atoms, and 3.2-3.5 $\times 10^{28}$ atoms $( \pm 10 \%)$ for the mid-1990s. These results were confirmed by Naegler and Levin (2006) using a different model, starting from a global bomb ${ }^{14} \mathrm{C}$ production estimate between 1945 and 1980 of $6.0-6.3 \times 10^{28}$ atoms. Based on these estimates, other important parameters could be reassessed: the air-sea gas exchange rate and the oceanic $\mathrm{CO}_{2}$ uptake rate. Sweeney et al. (2007) report updated estimates that are significantly lower than those from the early 1990s. For the air-sea gas exchange rate, they estimate $14.6 \pm 4.7$ $\mathrm{cm} / \mathrm{hr}$ (in rough agreement with Naegler and Levin 2006, but 33\% down from Wanninkhof 1992). Their corresponding value for the oceanic uptake of $\mathrm{CO}_{2}$ for the $1990 \mathrm{~s}$ is $1.8 \pm 0.5 \mathrm{PgC} / \mathrm{yr}$, lower but still in statistical agreement with an average value of $2.1 \pm 0.2 \mathrm{PgC} / \mathrm{yr}$ from other publications since 2000. Matsumoto (2007) revisits the question how ${ }^{14} \mathrm{C}$ can help to determine the circulation age of the world oceans. He uses the gridded data by Key et al. (2004) to establish a map of ${ }^{14} \mathrm{C}$ ages that takes proper account of surface reservoir ages. The measured ${ }^{14} \mathrm{C}$ levels at depths below $1500 \mathrm{~m}$ suggest maximum "ages" above $2000 \mathrm{yr}$ for the Pacific, whereas the corrected values are less than $1200 \mathrm{yr}$. Averages for the 4 main basins are $288 \mathrm{yr}$ (Atlantic), $889 \mathrm{yr}$ (Pacific), $716 \mathrm{yr}$ (Indian), and $295 \mathrm{yr}$ (Southern, with a $50^{\circ} \mathrm{S}$ northern boundary). Jones and collaborators (Jones et al. 1994) as well as Schlosser and collaborators (Schlosser et al. 1997) found a significantly higher replacement time ( $450 \mathrm{yr})$ than for the remainder of the Arctic Ocean in the deep waters of the Canadian Basin, effectively separated from the North Atlantic by the Lomonosov Ridge.

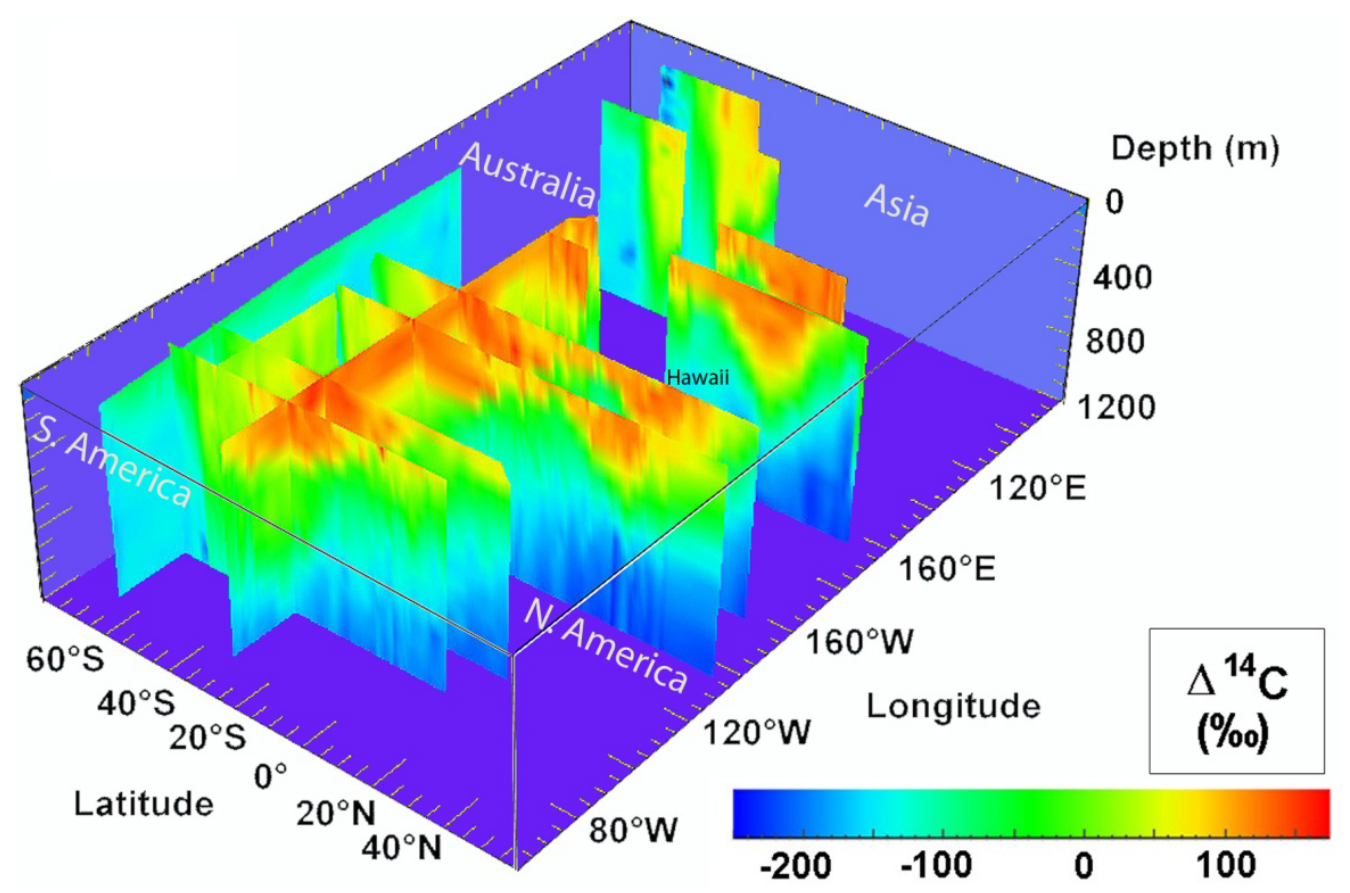

Figure 10 Distribution of ${ }^{14} \mathrm{C}$ in the upper $1200 \mathrm{~m}$ of the Pacific, Southern, and Indian Ocean basins in the 1990s. The penetration of ${ }^{14} \mathrm{C}$ generated by the nuclear bomb test series of the 1950s and 1960s is roughly indicated in the transition from green to light blue (assuming about $-60 \%$ as the pre-bomb $\Delta{ }^{14} \mathrm{C}$ ocean surface value). 


\section{Paleoceanography/Paleoclimatology}

Given the high degree of complexity involved in assessing modern ocean parameters, using ${ }^{14} \mathrm{C}$ as a tracer, it is not surprising that the reconstruction of past environments is no less difficult. The vast majority of samples (other than DIC) submitted to NOSAMS originate from sediments in the world oceans and lakes. However, a fair number of samples come from other marine sources like corals, mollusks, and speleothems. Since a large part of the NOSAMS activities was directed toward the WOCE project during the 1990s, the focus here will be mostly on the more recent past with respect to citations. One of the major questions throughout the $50 \mathrm{yr}$ of ${ }^{14} \mathrm{C}$ research has been the calibration of measurement results to a reliable timescale. Other laboratories using $\beta$-counting or AMS methods have carried the bulk of these analyses, limiting the NOSAMS contribution to a few sometimes shared efforts. Among these, Edouard Bard and colleagues have been very active in the attempt to extend the calibration curve beyond the "safe" terrestrial tree-ring curve, by analyzing Polynesian corals and Iberian Margin sediments (Bard et al. 2004a,b). Researchers in our own lab have aimed at expanding the knowledge of bomb ${ }^{14} \mathrm{C}$ history to the North Atlantic by analyzing mollusk shells growing at latitudes too cold for corals (Weidman and Jones 1993). Much of the paleoceanographic research focuses on the oceanic role in climate variability during the last ice age and the Holocene. Here, ${ }^{14} \mathrm{C}$ usually plays the role of a time marker perhaps in conjunction with other dating methods. For this reason, ${ }^{14} \mathrm{C}$ AMS measurements tend to be hidden in time axes on diagrams for other parameters. The actual source of the measurements is sometimes simply omitted (in which case the work is not cited in this review) or given only in supplemental material to the journal article. Here are some highlights from the last 2 decades. They include the work of Lloyd Keigwin and his collaborators on late Pleistocene and Holocene climate change events (Keigwin 1996, 2004; Keigwin and Pickart 1999; Keigwin et al. 2005, 2006; Keigwin and Boyle 2008). Much attention is given by many researchers to the role of the North Atlantic and its important part in the overall ocean circulation and climate change during these time periods (Came et al. 2003, 2008; Oppo et al. 2003; Rasmussen et al. 2003; McManus et al. 2004; Robinson et al. 2005; Lynch-Stieglitz et al. 2007). The effect of solar cycles on North Atlantic climate was discussed by Gerard Bond and colleagues, using AMS measurements from ETH Zürich, Arizona, and NOSAMS (Bond et al. 2001).

Related to these investigations is research on past sea levels, affecting coastal areas around the world. For instance, the ventilation of the Black Sea throughout this time period received special attention (Ballard et al. 2000; Çă̆atay et al. 2003; Giosan et al. 2006; Eriș et al. 2007; Ivanova et al. 2007). Work on corals and sclerosponges addressing more recent climate pattern questions is represented for example by (Grottoli et al. 2003; Cohen and Hart 2004; Rosenheim and Swart 2007). Figure 11 shows coral ${ }^{14} \mathrm{C}$ data from the Grottoli paper reflecting the excellent agreement of the AMS measurements performed at CAMS and NOSAMS, pinpointing the $+1.7 \% \Delta^{14} \mathrm{C}$ shift in 1947 at Fanning Island.

This decade has seen increasing interest in the history of storms and their effect on coastal areas. WHOI's Jeff Donnelly and Ilya Buynevich have been active in this area (Donnelly et al. 2004a,b; Buynevich et al. 2007; Donnelly and Woodruff 2007), analyzing, for example, storm surge sedimentation from historical storms.

Paleoclimate research dealing with terrestrial effects of regional and global climate patterns has made use of ${ }^{14} \mathrm{C}$ AMS dating at our facility. South American tropical climate history was discussed in Baker et al. (2001a,b). Growth behavior of tropical and subtropical fauna was the subject of several investigators (Bush et al. 2004; Biondi et al. 2007). Central and South African climate history during the late Holocene was investigated by Russell et al. (2003), Patrut et al. (2007), and Russell and Johnson (2007). 


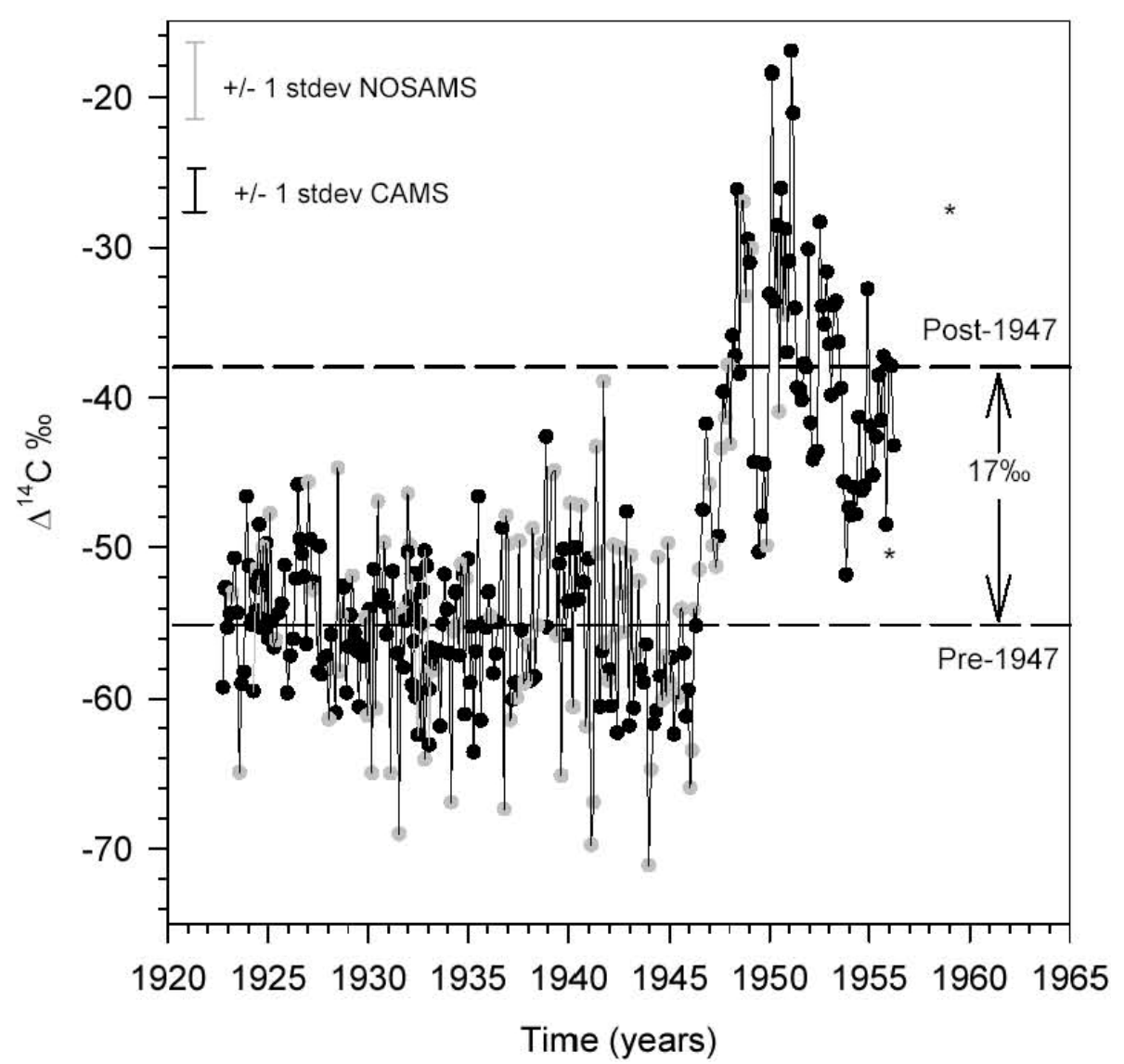

Figure 11 The excellent agreement between CAMS and NOSAMS analyses gives high levels of confidence in the timing of the shift in near-monthly skeletal ${ }^{14} \mathrm{C}$ of Fanning Island Porites corals. Two bulk annual ${ }^{14} \mathrm{C}$ measurements for 1956 and $1959\left(^{*}\right)$ are plotted as well (reprinted with permission from Grottoli et al. 2003).

While diverse in research direction, all of the paleoresearch above relies on a common assumption: new layers in sedimentation, shell and coral structures, and plant growth contain "younger" carbon than older layers. When age reversals occur in the data, explanations can range from errors in any stage of the analysis, reworking, bioturbation, to presence of carbon from sources other than the sample material of interest. If the analyzed material is a complex mixture of organic and inorganic carbon compounds, there is a good chance that the ${ }^{14} \mathrm{C}$ content of the individual compounds is different from that of the bulk sample. For this reason, there has been a substantial effort over the last 2 decades to develop methods to use AMS for the analysis of individual compounds in ever smaller sample sizes. Some of these new techniques also now allow the refinement of paleoresearch approaches. The following section will describe some of the efforts ongoing at the NOSAMS Facility and in its user community.

\section{Biogeochemistry and Microscale AMS}

Researchers using NOSAMS have played a major role in the development of the new compoundspecific ${ }^{14} \mathrm{C}$ analysis (CSRA) method, using chromatography to isolate specific compounds or compound classes from organic samples and trapping the effluents for later combustion and generation of very small AMS samples ( $<<100 \mu \mathrm{g} \mathrm{C}$ ) (Eglinton et al. 1997). The measurement of such small 
samples required a parallel development of microscale AMS techniques (Pearson et al. 1998; von Reden et al. 1998) matching similar efforts at other laboratories. Figure 12 shows an example of the large difference in dates obtained from individual compound groups in the same segment of a sediment core. The number of studies investigating the heterogeneity of carbon sources in environmental samples is growing fast. Polycyclic aromatic hydrocarbons (PAH) have been one of the subjects (Reddy et al. 2002a,b; Mandalakis et al. 2004; Gregory et al. 2005; Zencak et al. 2007). The origin of fatty acids in sediments has also been studied (Pearson et al. 2001; Hwang and Druffel 2003; Ohkouchi et al. 2003). Alkenones in sediments co-occurring with foraminifera were investigated by (Mollenhauer et al. 2003, 2005a,b). Discussion of carbon remineralization effects on sediments and transport of terrestrial carbon to the oceans can be found in Blair et al. (2003), Aller and Blair (2004 2006), and Drenzek et al. (2007). Many studies conclude that total carbon analyses can lead to erroneous dating results not only down core but also due to lateral redistribution of sediments. (For the latter, see e.g. Mollenhauer et al. 2006). The influx of anthropogenic carbon, mostly from fossil fuel burning and spills have been extensively investigated (Reddy et al. 2002a,b; Tanner et al. 2004; Slater et al. 2005, 2006; Smittenberg et al. 2005; White et al. 2005; Wakeham et al. 2006). Interestingly, not all suspected pollution indicators are necessarily man-made. Two papers report that certain halogenated organic compounds found in marine life are in fact natural products (Reddy et al. 2004; Teuten et al. 2005).

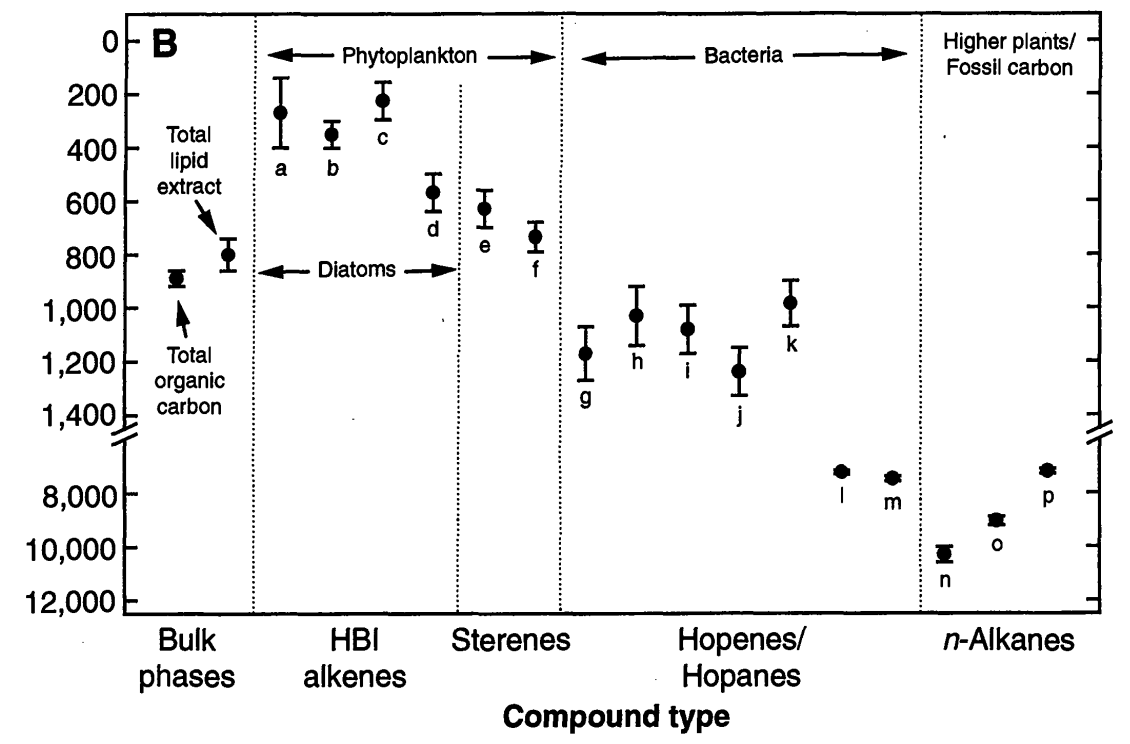

Figure 12 A sediment core segment (2- $4 \mathrm{~cm}$ ) from the Arabian Sea displays a 10,000-yr span in dates obtained from different organic compound groups. This clearly indicates the importance of the careful assessment of the carbonaceous components in a sample to obtain a reliable result (reprinted with permission from Eglinton et al. 1997).

CSRA to this date has one major drawback: it takes multiple chromatography runs and many hours of work to isolate enough material of a single compound to generate a viable AMS graphite sample. The last part of this section will describe the methods we are developing to deal with this problem. 


\section{Developments and Future Trends}

The equivalent of the search for the Golden Fleece in ${ }^{14} \mathrm{C}$ AMS has been the development of an efficient low-memory $\mathrm{CO}_{2}$ gas-accepting AMS ion source for something we have named: continuousflow ${ }^{14} \mathrm{C}$ analysis. Such a system would avoid the potentially contaminating graphitization step in the AMS analysis. So-called hybrid gas sources have been around for a while, but their operation requires either exchange of frits between samples or extensive time-consuming flushing, making the real-time analysis of rapidly incoming sample peaks from a chromatogram impossible. NOSAMS is currently commissioning a dedicated system for continuous-flow AMS analysis based on a microwave plasma ion source (Schneider et al. 1998; Kim et al. 2002; Han et al. 2007; Roberts et al. 2007; von Reden et al. 2007). Initial tests of the microwave source on our Tandetron system in 2002 have resulted in respectable currents $\left(-20 \mu \mathrm{A}{ }^{12} \mathrm{C}\right)$ from a $100-\mu \mathrm{L}$ modern sample $(\mathrm{OX}-1)$ for about 30 seconds, obtaining $\sim 600{ }^{14} \mathrm{C}$ counts. Figure 13 shows the first ever ${ }^{14} \mathrm{C}$ spectrum obtained with a microwave ion source during these tests (Kim et al. 2002). The conditions for that test were much less than optimal: the injector allowed only about $30 \%$ transmission, compounding the fact that the intrinsic ion efficiency of a positive ion plasma source coupled with a charge exchange canal is 10100 times lower than that of a traditional sputter source. The reduction in transmission stems from the fact that the emittance from a 5-mm-diameter plasma orifice is at least 2-3 times larger than that from a 1-mm sputter spot. For this reason, we designed the new system with a very large acceptance solid angle (see Han et al. 2007). The first benchmark results with a sputter ion source have confirmed the notion held by a number of AMS experts that a large acceptance also benefits traditional AMS, especially when currents of more than $150 \mu \mathrm{A}$ are extracted with notably higher emittance than more moderate currents would have.

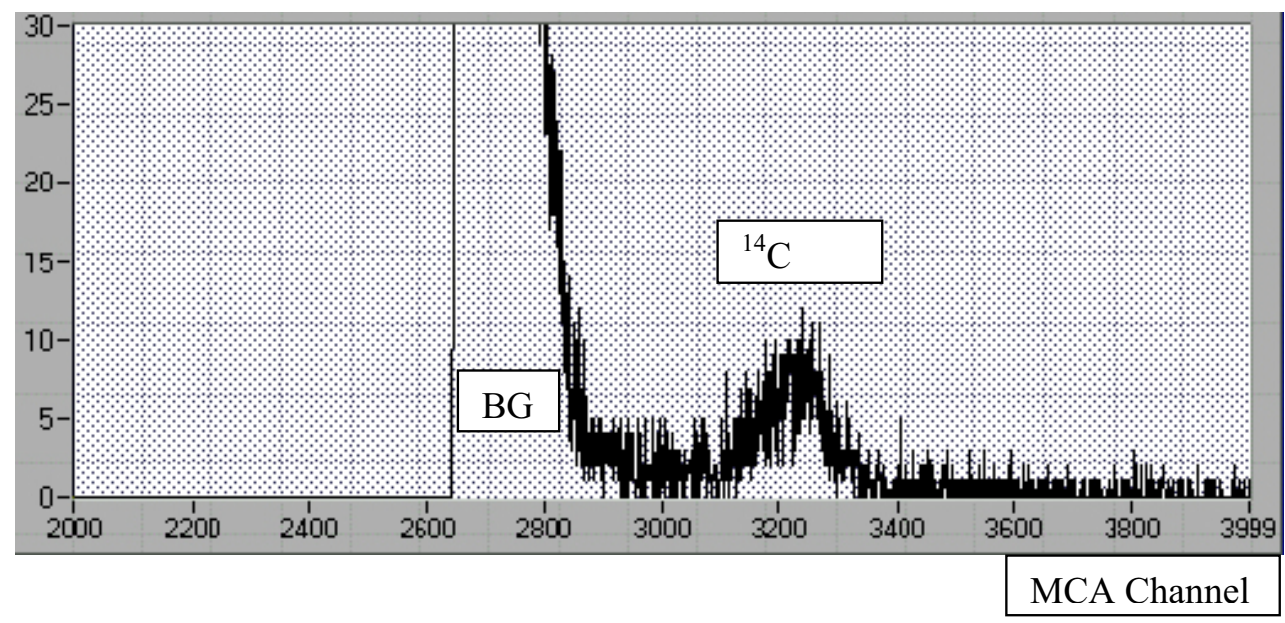

Figure 13 First AMS ${ }^{14} \mathrm{C}$ counts from a microwave gas ion source, recorded with a gas ionization detector. Substantial but well separated background events are caused by the poor match of the large emittance plasma source ion beam with the simultaneous injector of the NOSAMS Tandetron (witnessed by Gerlach et al. 2002).

The chromatographic efficiency problem mentioned above still poses a challenge to continuous-flow AMS. Without additional development of the injection scheme, AMS will have to be performed in multiple runs through a chromatogram (von Reden et al. 2008), to achieve sufficient statistics on a given compound of interest. However, recent development of very high throughput chromatography and combustions methods (McIntyre and Sylva 2008), boosting the carbon content of a single com- 
pound peak in a chromatogram to $\sim 1 \mu \mathrm{g}$, will allow an acceptable AMS analysis of a chromatogram in a single run!

\section{OUTLOOK}

We have seen that great developments have been made in ${ }^{14} \mathrm{C}$ science during the last $60 \mathrm{yr}$ when a simple gas counter with solid carbon sample was replaced either by proportional counters with active gas fillings, or by liquid scintillation spectrometers with benzene medium, and finally reached the present state-of-the-art technology based on coupling of a gas chromatograph with AMS for compound-specific ${ }^{14} \mathrm{C}$ analyses.

As a result of these developments, the analysis of long-lived radioactive isotopes, such as ${ }^{14} \mathrm{C}$, by ion counting and other methods is still developing in ways that almost defy prediction of future capability. However, the intense interest and the importance of ${ }^{14} \mathrm{C}$ dating and tracing as a technique continue to fascinate the researcher who will in the future have increasingly more compact equipment to use for such measurements. The research into the counting of beta-rays, atomic ions, and even atoms will all continue to produce answers to the problems first envisaged by W F Libby 60 yr ago.

It is our expectation that high-precision ${ }^{14} \mathrm{C}$ AMS will continue to rely on high-current sputter ion sources for the foreseeable future. The necessary precision for oceanic or atmospheric tracer measurements will require the highest possible ion efficiencies in AMS systems, placing the plasma ion sources at a disadvantage for these applications. However, in the field of paleoresearch we expect the increased use of CSRA to confirm or resolve discrepancies between different dating methods. The main field of expansion will most likely be in the field of biogeochemical (and medical) AMS, when dedicated AMS systems will be used in similar ways that stable isotope mass spectrometers are used now for analyzing chromatograms.

${ }^{14} \mathrm{C}$ dating by ${ }^{14} \mathrm{C}$ ion counting is not the only alternative to beta-ray counting, as has been shown in recent years. The use of lasers (Murnick et al. 2008) to excite the ${ }^{14} \mathrm{C}$ in a $\mathrm{CO}_{2}$ gas sample can result in the repeated detection of the same ${ }^{14} \mathrm{C}$ atoms in a sample so that their number can be estimated and the age determined. Alternatively, converting ${ }^{14} \mathrm{C}$ to ${ }^{15} \mathrm{C}$ by adding a neutron can shorten the lifetime as was done in 1965 for ${ }^{129} \mathrm{I}$ ( $16 \mathrm{Myr}$ half-life) by converting it to ${ }^{130} \mathrm{I}$ ( 9 min half-life) in a nuclear reactor (Watson et al. 1965). This gained a factor of $10^{12}$ in the decay rate as a result. The large 20-barn neutron cross-section for conversion of ${ }^{129} \mathrm{I}$ to ${ }^{130} \mathrm{I}$ makes this procedure possible and

it predated the first AMS measurements. In contrast, the thermal neutron capture cross-section for ${ }^{14} \mathrm{C}$ is less than $1 \mu$ barn and so a nuclear reaction such as the ${ }^{14} \mathrm{C}(\mathrm{d}, \mathrm{p}){ }^{15} \mathrm{C}$ would have to be used and the energetic beta-rays from ${ }^{15} \mathrm{C}$ counted. The half-life of ${ }^{15} \mathrm{C}$ is about $7 \times 10^{10}$ times shorter than ${ }^{14} \mathrm{C}$. However, unlike the case of ${ }^{129} \mathrm{I}$, this method does seem to be quite impractical, and it cannot compete with AMS.

While during the first $60 \mathrm{yr}$ of ${ }^{14} \mathrm{C}$ measurements, beta-counting, specifically gas counting, was the dominant technique, we believe that in the future AMS will be the dominant technology. Recent developments of very high throughput chromatography and combustions methods (McIntyre and Sylva 2008), will allow coupled GS-AMS analysis of a $\sim 1 \mu \mathrm{g}$ carbon content of a single compound peak in a gas chromatograph.

\section{ACKNOWLEDGMENTS}

We thank Prof Tim Jull, Editor of Radiocarbon, for his invitation to write this review. The development of ${ }^{14} \mathrm{C}$ dating by beta-counting and AMS was an international undertaking and this review can 
only mention a few of the contributions. Many colleagues participated in various stages of development of ${ }^{14} \mathrm{C}$ techniques in our laboratories. We wish to acknowledge at least some of them.

PPP is indebted to his colleagues at the Faculty, particularly Martin Chudý, Štefan Šáro, Mojmír Šeliga, and Alexander Šivo and many graduate students for fruitful collaboration. Further, he thanks colleagues at the International Atomic Energy Agency's Marine Environment Laboratories in Monaco, namely Laval Liong Wee Kwong, Sang-Han Lee, and Ben Oregioni for their help in radiometric and AMS developments. He is also indebted to Tim Jull, Devendra Lal, Reider Nydal, Kako Pagava, Soma Somayajulu, and Orihiko Togawa, as well as the late Tsutsna Burchuladze, KO Münnich, and Hans Oeschger for their cooperation and support during various stages of ${ }^{14} \mathrm{C}$ techniques developments.

AEL is principally indebted to Dr K H Purser and Professor H E Gove for their unflagging enthusiasm during the difficult early days of AMS, and to the many graduate students who contributed significantly to the development, particularly the late Dr L R Kilius. His thanks also go to the Italian Committee who hosted a 30-yr retrospect on AMS at AMS 11 in Rome during September 2008 with a chance to look back on a period of AMS that was almost as fascinating as the early days with the first tandem accelerator at the Atomic Energy of Canada Laboratories in Chalk River during 1959. $\mathrm{He}$ also reread both the Proceedings to the first AMS Conference on "Radiocarbon Dating with Accelerators" and those of the Proceedings of the second AMS Conference, which are now available on the internet thanks to the enterprise of Walter Kutschera. The web sites are to be found in the references and are recommending the document to those who want to get a real feeling for the early days of AMS.

$\mathrm{KvR}$ is indebted to his present and former colleagues at the NOSAMS Facility, which since its establishment in 1989 has been supported by the US National Science Foundation through multiple Cooperative Agreements.

\section{REFERENCES}

Aberth W, Peterson JR. 1967. Characteristics of a low energy duoplasmatron negative ion source. Review of Scientific Instruments 38:745-8.

Alimonti G, Borexino collaboration. 1998. Measurement of the ${ }^{14} \mathrm{C}$ abundance in a low-background liquid scintillator. Physics Letters B 422(1-4):349-58.

Aller RC, Blair NE. 2004. Early diagenetic remineralization of sedimentary organic $\mathrm{C}$ in the Gulf of Papua deltaic complex (Papua New Guinea): net loss of terrestrial $\mathrm{C}$ and diagenetic fractionation of $\mathrm{C}$ isotopes. Geochimica et Cosmochimica Acta 68(8):1815-25.

Aller RC, Blair NE. 2006. Carbon remineralization in the Amazon-Guianas mobile mudbelt: a sedimentary incinerator. Continental Shelf Research 26:2241-59.

Alvarez LW, Cornog R. 1939a. $\mathrm{He}^{3}$ in helium. Physical Review 56:379.

Alvarez LW, Cornog R. 1939b. Helium and hydrogen of mass 3. Physical Review 56:613.

Alvarez LW. 1951. Energy doubling in dc accelerators. Review of Scientific Instruments 22:705-6.

Alvarez LW. 1981. The early days of accelerator mass spectrometry. In: Henning W, Kutschera W, Smitherand R, Yntema JL, editors. Proceedings of the Second International Conference on AMS. Argonne Na- tional Laboratory, Physics Division, ANL/PHY-81-1. Available at http://homepage.univie.ac.at/walter.kutschera/AMS/AMS-2.pdf.

Anbar M. 1975. Mass Spectrometric Determination of Carbon 14. US Patent 3,885,155.

Anbar M. 1978. The limitations of mass spectrometric radiocarbon dating using $\mathrm{CN}$ ions. In: HE Gove, editor. Proceedings of the First Conference on Radiocarbon Dating with Accelerators. Rochester: University of Rochester. p 152-6. Available at http://homepage.univie.ac.at/walter.kutschera/AMS/AMS-1.pdf.

Anderson EC, Libby WF. 1951. World-wide distribution of natural radiocarbon. Physical Review 81:64-9.

Anderson EC, Libby WF, Weinhouse S, Reid AF, Kirschenbaum AD, Grosse AV. 1947. Radiocarbon from cosmic radiation. Science 105(2735):576-7.

Anderson EC, Arnold JR, Libby WF. 1951. Measurements of low level radiocarbon. Review of Scientific Instruments 22:225-30.

Arnold JR. 1954. Scintillation counting of radiocarbon: I. The counting method. Science 119(3083):155-7.

Arnold JR. 1987. Decay counting in the age of AMS. Nuclear Instruments and Methods in Physics Research B 29(1-2):424-6. 
Arnold JR, Libby WF. 1949. Age determination by radiocarbon content: checks with samples of known age. Science 110(2869):678-80.

Arpesella C, Borexino collaboration. 2008. Direct measurement of the ${ }^{7} \mathrm{Be}$ solar neutrino flux with 192 days of Borexino data. Physical Review Letters 101: 091302.

Asi A. 2001. Ion source modeling with Lorentz-2D. Available at http://www.integratedsoft.com/Papers/ research/ICIS2001.pdf.

Audric BN, Long JVP. 1954. Use of dissolved acetylene in liquid scintillation counters for the measurement of carbon-14 of low specific activity. Nature 173(4412): 992-3.

Baker PA, Rigsby CA, Seltzer GO, Fritz SC, Lowenstein TK, Bacher NP, Veliz C. 2001a. Tropical climate changes at millennial and orbital timescales on the Bolivian Altiplano. Nature 409(6821):698-701.

Baker PA, Seltzer GO, Fritz SC, Dunbar RB, Grove MJ, Tapia PM, Cross SL, Rowe HD, Broda JP. 2001b. The history of South American tropical precipitation for the past 25,000 years. Science 291(5504):640-3.

Ballard RD, Coleman DF, Rosenberg GD. 2000. Further evidence of abrupt Holocene drowning of the Black Sea shelf. Marine Geology 170(3-4):253-61.

Bandura DR, Baranov VI, Litherland AE, Tanner SD. 2006. Gas-phase ion-molecule reactions for resolution of atomic isobars: AMS and ICP-MS perspectives. International Journal of Mass Spectrometry 255-256: 312-27.

Bard E, Ménot-Combes G, Rostek F. 2004a. Present status of radiocarbon calibration and comparison records based on Polynesian corals and Iberian Margin sediments. Radiocarbon 46(3):1189-202.

Bard E, Rostek F, Ménot-Combes G. 2004b. Paleoclimate: a better radiocarbon clock. Science 303(5655): 178-9.

Barendsen GW. 1957. Radiocarbon dating with liquid $\mathrm{CO}_{2}$ as diluent in a scintillation solution. Review of Scientific Instruments 28:430-2.

Bell CG, Hayes FN, editors. 1958. Liquid Scintillation Counting. London: Pergamon Press.

Bennett CL, Beukens RP, Clover MR, Elmore D, Gove HE, Kilius L, Litherland AE, Purser KH. 1978. Radiocarbon dating with electrostatic accelerators: dating of milligram samples. Science 201(4353):345-7.

Bennett WH. 1940. High Voltage Vacuum Tube. US Patent No. 2,206,558.

Berger R, Suess HE, editors. 1979. Radiocarbon Dating. Proceedings of the Ninth International Conference. Los Angeles and La Jolla 1976. Berkeley: University of California Press.

Berkovits D, Boaretto E, Hollos G, Kutschera W, Naaman R, Paul M, Vager Z. 1989. Selective suppression of negative ions by lasers. Nuclear Instruments and Methods in Physics Research A 281(3):663-6.

Bertsche KJ, Karadi CA, Muller RA, Paulson GC. 1990.
Detection of radiocarbon in the cyclotrino. Nuclear Instruments and Methods in Physics Research B 52(34):398-404.

Beukens RP. 1992. Radiocarbon accelerator mass spectrometry: background, precision and accuracy. In: Taylor RE, Long A, Kra RS, editors. Radiocarbon After Four Decades. An Interdisciplinary Perspective. New York: Springer Verlag. p 230-9.

Beukens RP. 1993. Radiocarbon accelerator mass spectrometry: background and contamination. Nuclear Instruments and Methods in Physics Research B 79(14):620-3.

Beukens RP, Gove HE, Litherland AE, Kieser WE, Zhao X-L. 2004. The old carbon project: how old is old? Nuclear Instruments and Methods in Physics Research B 223-224:333-8.

Biondi F, Strachan SDJ, Mensing S, Piovesan G. 2007. Radiocarbon analysis confirms the annual nature of sagebrush growth rings. Radiocarbon 49(3):1231-40.

Blackett PMS, Occhialini GPS. 1933. Some photographs of the tracks of penetrating radiation. Proceedings of the Royal Society A 139(839):699-726.

Blair NE, Leithold EL, Ford ST, Peeler KA, Holmes JC, Perkey DW. 2003. The persistence of memory: the fate of ancient sedimentary organic carbon in a modern sedimentary system. Geochimica et Cosmochimica Acta 67(1):63-73.

Bond G, Kromer B, Beer J, Muscheler R, Evans MN, Showers W, Hoffmann S, Lotti-Bond R, Hajdas I, Bonani G. 2001. Persistent solar influence on north Atlantic climate during the Holocene. Science 294(5549):2130-6.

Bonner TW, Brubaker WM. 1936. The disintegration of nitrogen by neutrons. Physical Review 49:223-9.

Brannon HR, Taggart Jr MS, Williams M. 1955. Proportional counting of carbon dioxide for radiocarbon dating. Review of Scientific Instruments 26:269-73.

Broecker WS, Tucek CS, Olson EA. 1959. Radio-carbon analysis of oceanic $\mathrm{CO}_{2}$. International Journal of Applied Radiation and Isotopes 7(1):1-10.

Broecker WS, Sutherland S, Smethie W, Peng T-H, Ostlund G. 1995. Oceanic radiocarbon: separation of the natural and bomb components. Global Biogeochemical Cycles 9(2):263-88.

Bromley DA, editor. 1974. Large electrostatic accelerators. Nuclear Instruments and Methods 122:1-285.

Brooks FD. 1958. In: Bell CG, Hayes FN, editors. Liquid Scintillation Counting. London: Pergamon. p 268.

Burcham WE, Goldhaber M. 1936. The disintegration of nitrogen by slow neutrons. Proceedings of the Cambridge Philosophical Society 32(4):632-6.

Burchuladze AA, Pagava SV, Povinec P, Togonidze GI, Usačev S. 1980. Radiocarbon variations with the 11year solar cycle during the last century. Nature 287(5780):320-2.

Burke Jr WH, Meinschein WG. 1955. $\mathrm{C}^{14}$ dating with a methane proportional counter. Review of Scientific In- 
struments 26:1137-40.

Bush MB, Silman MR, Urrego DH. 2004. 48,000 years of climate and forest change in a biodiversity hot spot. Science 303(5659):827-9.

Buynevich IV, FitzGerald DM, Goble RJ. 2007. A 1500 yr record of North Atlantic storm activity based on optically dated relict beach scarps. Geology 35(6):5436.

Çağatay MN, Görür N, Polonia A, Demirbağ E, Saknç M, Cormier M-H, Capotondi L, McHugh C, Emre Ö, Eriș K. 2003. Sea-level changes and depositional environments in the Izmir Gulf, eastern Marmara Sea, during the late glacial-Holocene period. Marine Geology 202(3-4):159-73.

Came RE, Oppo DW, Curry WB. 2003. Atlantic Ocean circulation during the Younger Dryas: insights from a new $\mathrm{Cd} / \mathrm{Ca}$ record from the western subtropical South Atlantic. Paleoceanography 18(4): 1086, doi: 10.1029/2003PA000888.

Came RE, Oppo DW, Curry WB, Lynch-Stieglitz J. 2008. Deglacial variability in the surface return flow of the Atlantic meridional overturning circulation. Paleoceanography 23: PA1217, doi: 10.1029/ 2007PA001450.

Chapman K, editor. 1972. Proceedings of the Symposium of North East Accelerator Personnel. Tallahassee: Florida State University. (See particularly p 100-4.)

Charalambus S, Goebel K. 1963. Low level proportional counter for tritium. Nuclear Instruments and Methods 25:109-17.

Chen M, Lu X, Li D, Liu Y, Zhou W, Chen G, Shen L, Xu S, Zhang Y. 2000. Minicyclotron (SMCAMS)-based accelerator mass spectrometry and real ${ }^{14} \mathrm{C}$ measurements. Nuclear Instruments and Methods in Physics Research B 172(1-4):193-200.

Cohen AL, Hart SR. 2004. Deglacial sea surface temperatures of the western tropical Pacific: a new look at old coral. Paleoceanography 19: PA4031, doi: 10.1029/ 2004PA001084.

Collon P, Kutschera W, Loosli HH, Lehmann BE, Purtschert R, Love A, Sampson L, Anthony D, Cole D, Davids B, Morrisey DJ, Sherrill BM, Steiner M, Pardo RC, Paul M. 2000. ${ }^{81} \mathrm{Kr}$ in the Great Artesian Basin, Australia: a new method for dating very old groundwater. Earth and Planetary Science Letters 182(1):103-13.

Crathorn AR. 1953. Use of an acetylene-filled counter for natural radiocarbon. Nature 172(4379):632-3.

Curran SC, Angus J, Cockroft AL. 1949. Investigation of soft radiations by proportional counters. I. Philosophical Magazine 40:36-52.

Currie LA, Noakes JE, Breiter DN. 1978. Measurement of small radiocarbon samples: power of alternative methods for tracing atmospheric hydrocarbons. In: Berger R, Suess HE, editors. Radiocarbon Dating. Proceedings of the Ninth International Conference Los Angeles and La Jolla, 1976. Berkeley: University of California Press. p 158-75.
Currie LA, Gerlach RW, Klouda GA, Ruegg FC, Tompkins GB. 1983. Miniature signals and miniature counters: accuracy assurance via microprocessors and multiparameter control techniques. Radiocarbon 25(2):553-64.

Damon PE, Long A, Grey DC. 1966. Fluctuation of atmospheric $\mathrm{C}^{14}$ during the last six millennia. Journal of Geophysical Research 71(4):1055-63.

Davis Jr R, Harmer DS, Hoffman KC. 1968. Search for neutrinos from the Sun. Physical Review Letters 20(21):1205-9.

de Vries H. 1956. The contribution of neutrons to the background of counters used for ${ }^{14} \mathrm{C}$ age measurements. Nuclear Physics 1(6):477-9.

de Vries H, Barendsen GW. 1952. A new technique for the measurement of age by radiocarbon. Physica 18 : 652-9.

de Vries H, Barendsen GW. 1953. Radiocarbon dating by a proportional counter filled with carbon dioxide. Physica 19:987-1003.

Donnelly JP, Woodruff JD. 2007. Intense hurricane activity over the past 5,000 years controlled by El Niño and the West African monsoon. Nature 447(7143):465-8.

Donnelly JP, Butler J, Roll S, Wengren M, Webb III T. 2004a. A backbarrier overwash record of intense storms from Brigantine, New Jersey. Marine Geology 210(1-4):107-21.

Donnelly JP, Cleary P, Newby P, Ettinger R. 2004b. Coupling instrumental and geological records of sea-level change: evidence from southern New England of an increase in the rate of sea-level rise in the late 19th century. Geophysical Research Letters 31: L05203, doi: 10.1029/2003GL018933.

Drenzek NJ, Montluçon DB, Yunker MB, Macdonald RW, Eglinton TI. 2007. Constraints on the origin of sedimentary organic carbon in the Beaufort Sea from coupled molecular ${ }^{13} \mathrm{C}$ and ${ }^{14} \mathrm{C}$ measurements. Marine Chemistry 103(1-2):146-62.

Drever RWP, Moljk A, Curran SC. 1957. A proportional counter system with small wall effect. Nuclear Instruments 1:41-5.

Eglinton TI, Benitez-Nelson BC, Pearson A, McNichol AP, Bauer JE, Druffel ERM. 1997. Variability in radiocarbon ages of individual organic compounds from marine sediments. Science 277(5327):796-9.

Elmore D, Kubik PW, Tubbs LE, Gove HE, Teng R, Hemmick T, Chrunyk B, Conard N. 1984. The Rochester tandem accelerator mass spectrometer program. Nuclear Instruments and Methods in Physics Research B 5(2):109-16.

Engelkemeir AG, Hamill WH, Inghram MG, Libby WF. 1949. The half-life of radiocarbon $\left({ }^{14} \mathrm{C}\right)$. Physical Review 75:1825-33.

Eriş KK, Ryan WBF, Çağatay MN, Sancar U, Lericolais G, Ménot G, Bard E. 2007. The timing and evolution of the post-glacial transgression across the Sea of Marmara shelf south of Istanbul. Marine Geology 243(1-4):57-76. 
Fallon SJ, Guilderson TP, Brown TA. 2007. CAMS/ LLNL ion source efficiency revisited. Nuclear Instruments and Methods in Physics Research B 259(1): $106-10$.

Faltings V. 1952. Die Messung natürlicher ${ }^{14} \mathrm{C}$-Aktivitäten in proportionalzähler. Naturwissenschaften 39: 378-9. In German.

Fergusson GJ. 1955. Radiocarbon dating system. Nucleonics $13: 18-23$.

Fifield LK. 2000. Advances in AMS. Nuclear Instruments and Methods in Physics Research B 172(1-4): $134-43$.

Forstner O, Andersson P, Diehl C, Golser R, Hanstorp D, Kutschera W, Lindahl A, Priller A, Steier P, Wallner A. 2008. Isobar suppression in AMS using laser photodetachment. Nuclear Instruments and Methods in Physics Research B 266(19-20):4565-8.

Geiger H, Müller W. 1929. Technische Bemerkungen zum Elektronenzäherohr. Zeitschrift für Physik 30: 489. In German.

Gerlach D, Griffin V, Kim S-W, Long P, McNichol A, Percy D, Schneider R, von Reden K, Zondervan A. 2002. Witnesses to the first ${ }^{14} \mathrm{C}$ events from a microwave gas ion source, recorded with the NOSAMS AMS gas detector (18 January 2002).

Geyh MA. 1967. Experience gathered in the construction of low-level counters. In: Radioactive Dating and Methods of Low-Level Counting. Vienna: IAEA. p 575-91.

Giosan L, Donnelly JP, Constantinescu S, Filip F, Ovejanu I, Vespremeanu-Stroe A, Vespremeanu E, Duller GAT. 2006. Young Danube delta documents stable Black Sea level since the middle Holocene: morphodynamic, paleogeographic, and archaeological implications. Geology 34(9):757-60.

Gnaser H. 1997. Formation of metastable $\mathrm{N}_{2}^{-}$and $\mathrm{CO}^{-}$ anions in sputtering. Physical Review A 56(4):R2518 21.

Gnaser H. 2008. Isotopic fractionation of sputtered anions: $\mathrm{C}^{-}$and $\mathrm{C}^{-2}$. Nuclear Instruments and Methods in Physics Research B 266(1):37-43.

Gove HE. 1999. From Hiroshima to the Iceman: The Development and Applications of Accelerator Mass Spectrometry. Bristol: Institute of Physics Publishing. $226 \mathrm{p}$.

Gregory ST, Shea D, Guthrie-Nichols E. 2005. Impact of vegetation on sedimentary organic matter composition and polycyclic aromatic hydrocarbon attenuation. Environmental Science \& Technology 39(14):528592.

Grootes PM. 1977. Enrichment of radiocarbon for dating samples up to 75,000 years. In: Povinec P, Usačev S, editors. Low-Radioactivity Measurements and Applications. Proceedings of the International Conference, High Tatras, 1975. Bratislava: Slovenské Pedagogické Nakladatestvo. p 93-7.

Grottoli AG, Gille ST, Druffel ERM, Dunbar RB. 2003. Decadal timescale shift in the ${ }^{14} \mathrm{C}$ record of a central equatorial Pacific coral. Radiocarbon 45(1):91-9.

Hall ET, Hedges REM, White NR, Hyder HR, Sinclair D. 1978. Plans for Van de Graaff mass spectrometry and laser enrichment of ${ }^{14} \mathrm{C}$ at Oxford. In: Gove HE, editor. Proceedings of the First Conference on Radiocarbon Dating with Accelerators. Rochester: University of Rochester. p 257-65. Available at http://homepage.univie.ac.at/walter.kutschera/AMS/AMS-1.pdf.

Han BX, von Reden KF, Roberts ML, Schneider RJ, Hayes JM, Jenkins WJ. 2007. Electromagnetic field modeling and ion optics calculations for a continuousflow AMS system. Nuclear Instruments and Methods in Physics Research B 259(1):111-7.

Harbottle G, Sayre EV, Stoenner RW. 1979. Carbon-14 dating of small samples by proportional counting. Science 206(4419):683-5.

Hellborg R, editor. 2005. Electrostatic Accelerators: Fundamentals and Applications. Berlin: Springer. $620 \mathrm{p}$.

Henning W. 1987. Accelerator mass spectrometry of the heavy elements: ${ }^{36} \mathrm{Cl}$ to ${ }^{205} \mathrm{~Pb}$. Philosophical Transaction of the Royal Society of London A 323(1569):8799.

Hesshaimer V, Heimann M, Levin I. 1994. Radiocarbon evidence for a smaller oceanic carbon dioxide sink than previously believed. Nature 370(6486):201-3.

Hogg A, Polach H, Robertson S, Noakes J. 1991. Application of high purity synthetic quartz vials to liquid scintillation low-level ${ }^{14} \mathrm{C}$ counting of benzene. In: Ross H, Noakes JE, Spaulding JD, editors. Liquid Scintillation Counting and Organic Scintillators. Chelsea: Lewis Publishers. p 123-31.

Horrocks DL. 1974. Applications of Liquid Scintillation Counting. New York: Academic Press. 346 p.

Houtermans FG, Oeschger H. 1955. Proportionszählrohr zur Messung schwacher Aktivitäten weicher -Strahlung. Helvetica Physica Acta 28:464-6. In German.

Hut G, Keyser J, Wijma S. 1983. A multiple proportional ${ }^{14} \mathrm{C}$ counter system for milligram-sized samples. 1983. Radiocarbon 25(2):547-52.

Hwang J, Druffel ERM. 2003. Lipid-like material as the source of the uncharacterized organic carbon in the ocean? Science 299(5608):881-4.

Ishikawa J. 1995. Negative ion sources. In: Wolf B, editor. Handbook of Ion Sources. Chapter 2, section 16. New York: CRC Press. p 289-312.

Ivanova EV, Murdmaa IO, Chepalyga AL, Cronin TM, Pasechnik IV, Levchenko OV, Howe SS, Manushkina AV, Platonova EA. 2007. Holocene sea-level oscillations and environmental changes on the eastern Black Sea shelf. Palaeogeography, Palaeoclimatology, Palaeoecology 246(2-4):228-59.

Jones GA, McNichol AP, von Reden KF, Schneider RJ. 1990. The National Ocean Sciences AMS facility at Woods Hole Oceanographic Institution. Nuclear Instruments and Methods in Physics Research B 52(34):278-84

Jones GA, Gagnon AR, von Reden KF, McNichol AP, 
Schneider RJ. 1994. High-precision AMS radiocarbon measurements of central Arctic-Ocean sea waters. $\mathrm{Nu}$ clear Instruments and Methods in Physics Research B 92(1-4):426-30.

Jull AJT, Burr GS, Beck JW, Hodgins GWL, Biddulph DL, McHargue LR, Lange TE. 2008. Accelerator mass spectrometry of long-lived light radionuclides In: Povinec P, editor. Analysis of Environmental Radionuclides. Amsterdam: Elsevier. p 241-62.

Kalin RM, Devine JM, Long A. 1991. Performance of small quartz vials in a low-level, high resolution liquid scintillation spectrometer. In: Ross H, Noakes JE, Spaulding JD, editors. Liquid Scintillation Counting and Organic Scintillators. Chelsea: Lewis Publishers. p 471-9.

Kallmann HI, Kuhn E. 1940. Device for Generating a Beam of Ions of High Velocity. US Patent No. $2,213,140$.

Keigwin LD. 1996. The little ice age and medieval warm period in the Sargasso Sea. Science 274(5292):15048.

Keigwin LD. 2004. Radiocarbon and stable isotope constraints on Last Glacial Maximum and Younger Dryas ventilation in the western North Atlantic. Paleoceanography 19(4): PA4012, doi: 10.1029/ 2004 PA001029.

Keigwin LD, Boyle EA. 2008. Did North Atlantic overturning halt 17,000 years ago? Paleoceanography 23(1): PA1101, doi: 10.1029/2007PA001500.

Keigwin LD, Pickart RS. 1999. Slope water current over the Laurentian fan on interannual to millennial time scales. Science 286(5439):520-3.

Keigwin LD, Sachs JP, Rosenthal Y, Boyle EA. 2005. The 8200 year BP event in the slope water system, western subpolar North Atlantic. Paleoceanography 20(2): PA2003, doi: 10.1029/2004PA001074.

Keigwin LD, Donnelly JP, Cook MS, Driscoll NW, Brigham-Grette J. 2006. Rapid sea-level rise and Holocene climate in the Chukchi Sea. Geology 34(10): $861-4$.

Key R. 1996. WOCE Pacific Ocean radiocarbon program. Radiocarbon 38(3):415-23.

Key RM, Quay PD, Jones G, McNichol AP, von Reden KF, Schneider RJ. 1996. WOCE AMS radiocarbon I: Pacific Ocean results (P6, P16 and P17). Radiocarbon 38(3):425-518.

Key RM, Quay PD, Schlosser P, McNichol AP, von Reden KF, Schneider RJ, Elder K, Stuiver M, Ostlund H. 2002. WOCE radiocarbon IV: Pacific Ocean results; P10, P13N, P14C, P18, P19 \& S4P. Radiocarbon 44(1):239-392.

Key RM, Kozyr A, Sabine CL, Lee K, Wanninkhof R, Bullister JL, Feely RA, Millero FJ, Mordy C, Peng TH. 2004. A global ocean carbon climatology: results from Global Data Analysis Project (GLODAP). Global Biogeochemical Cycles 18(4): GB4031, doi: 10.1029/2004GB002247.
Kilius LR, Rucklidge JC, Litherland AE. 1987. Accelerator mass spectrometry of ${ }^{129}$ I at IsoTrace. Nuclear Instruments and Methods B 29(1-2):72-6.

Kim S-W, Schneider RJ, von Reden KF, Hayes JM, Wills JSC. 2002. Test of negative ion beams from a microwave ion source with a charge exchange canal for accelerator mass spectrometry applications. Review of Scientific Instruments 73:846-8.

Kitagawa H, van der Plicht J. 1998. Atmospheric radiocarbon calibration to 45,000 yr B.P.: late glacial fluctuations and cosmogenic isotope production. Science 279(5354):1187-90.

Kubik PW, Elmore D. 1989. AMS of ${ }^{41} \mathrm{Ca}$ using the $\mathrm{CaF}_{3}$ negative ion. Radiocarbon 31(3):324-6.

Kuehner JA, Almqvist E, Bromley DA. 1960. In: Bromley DA, Vogt EW, editors. Proceedings of the 1960 International Conference on Nuclear Structure. Toronto: University of Toronto Press. p 280.

Kurie FND. 1934. A new mode of disintegration induced by neutrons. Physical Review 45:904-5.

Kutschera W. 2005. Progress in isotope analysis of at ultra-trace level by AMS. International Journal of Mass Spectrometry 242(2-3):145-60.

Lal D. 1965. In: Chatters RM, editor. Proceedings of the Sixth International Conference Radiocarbon and Tritium Dating. Pullman, Washington, 7-11 June 1965 (Conf. 650652). p 487.

Laney BH. 1971. Electronic rejection of optical crosstalk in a twin phototube scintillation counter. In: Organic Scintillator and Liquid Scintillation Counting. New York: Academic Press. p 991-1003.

Lee HW, Galindo-Uribarri A, Chang KH, Kilius LR, Litherland AE. 1984. The ${ }^{12} \mathrm{CH}_{2}{ }^{2+}$ molecule and radiocarbon dating by accelerator mass spectrometry. Nuclear Instruments and Methods in Physics Research B 5(2):208-10.

Libby WF. 1934. Radioactivity of neodymium and samarium. Physical Review 46:196-204.

Libby WF. 1946. Atmospheric helium three and radiocarbon from cosmic radiation. Physical Review 69: 671-2.

Libby WF. 1955. Radiocarbon Dating. 2nd edition. Chicago: University of Chicago Press. 175 p.

Libby WF. 1967. History of radiocarbon dating. In: $R a-$ dioactive Dating and Methods of Low-Level Counting. Proceedings of the Symposium Vienna, 1967. Vienna: IAEA. p 3-26.

Libby WF, Lee DD. 1939. Energies of soft beta-radiations of rubidium and other bodies. Method for their determination. Physical Review 55:245-51.

Litherland AE. 1962. Negative Ion Production Studies. Progress Report of the Physics Division. Atomic Energy of Canada Limited, PR-P-56, p 2.7.

Litherland AE. 1978. Radiocarbon dating with accelerators. In: Gove HE, editor. Proceedings of the First Conference on Radiocarbon Dating with Accelerators. Rochester: University of Rochester. p 70-113. 
Available at http://homepage.univie.ac.at/walter.kutschera/AMS/AMS-1.pdf.

Litherland AE. 1984. Accelerator mass spectrometry. Nuclear Instruments and Methods in Physics Research B 5(2):100-8.

Litherland AE, Kilius LR. 1990. A recombinator for radiocarbon accelerator mass spectrometry. Nuclear Instruments and Methods in Physics Research B 52(34):375-7.

Litherland AE, Kuehner JA, Gove HE, Clark MA, Almqvist E. 1961. Rotational bands in ${ }^{20} \mathrm{Ne}$. Physical Review Letters 7:98-100.

Litherland AE, Gove HE, Beukens RP, Zhao X-L, Kieser WE. 2005. Low-level ${ }^{14} \mathrm{C}$ measurements and accelerator mass spectrometry. In: Cleveland B, Ford R, Chen M, editors. Topical Workshop on Low Radioactivity Techniques, Conference Proceedings of the AIP. CP 785. p 48-56. (Note: in the published paper there is a typographical error in line 15 of the introduction. The exponent should be 18 not 16.).

Litherland AE, Tomski I, Zhao X-L, Cousins LM, Doupé JP, Javahery G, Kieser WE. 2007. Isobar separation at very low energy for AMS. Nuclear Instruments and Methods in Physics Research B 259(1):230-5.

Long A, Kalin RM. 1992. Radiocarbon dating in the 50,000 to 65,000 year range without isotopic enrichment. In: Povinec P, editor. Rare Nuclear Processes. Proceedings of the 14th Europhysics Conference on Nuclear Physics. Bratislava: Veda Publishers. p 25663.

Loosli HH, Oeschger H. 1982. Low-level gas proportional counting in an underground laboratory. In: Povinec P, editor. Low-Level Counting. Proceedings of the 2nd International Conference Low Radioactivities High Tatras, 1980. Bratislava: Veda Publishers. Volume 1. p 117-25.

Loosli HH, Möll M, Oeschger H, Scotterer U. 1986. Ten years low-level counting in the underground laboratory in Bern, Switzerland. Nuclear Instruments and Methods in Physics Research B 17(5-6):402-5.

Lu Z-T, Wendt KDA. 2003. Laser-based methods for ultrasensitive trace-isotope analyses. Review of Scientific Instruments 74:1169-79.

Lynch-Stieglitz J, Adkins JF, Curry WB, Dokken T, Hall IR, Herguera JC, Hirschi J-M, Ivanova EV, Kissel C, Marchal O, Marchitto TM, McCave IN, McManus JF, Mulitza S, Ninnemann U, Peeters F, Yu E-F, Zahn R. 2007. Atlantic meridional overturning circulation during the last glacial maximum. Science 316(5821):669.

Mandalakis M, Gustafsson Ö, Reddy CM, Xu L. 2004. Radiocarbon apportionment of fossil versus biofuel combustion sources of polycyclic aromatic hydrocarbons in the Stockholm metropolitan area. Environmental Science \& Technology 38(20):5344-9.

Mäntynen P, Aikää O, Kankainen T, Kaihola L. 1987. Application of pulse-shape discrimination to improve the precision of the carbon-14 gas-proportional-counting method. Applied Radiation and Isotopes 38(10): 869-73.

Marrodán Undagoitia T, von Feilitzsch F, Göger-Neff M, Hochmuth KA, Oberauer L, Potzel W, Wurm M. 2006. Low energy neutrino astronomy with the large liquid-scintillation detector LENA. Journal of Physics: Conference Series 57:283-9.

Matsumoto K. 2007. Radiocarbon-based circulation age of the world oceans. Journal of Geophysical Research 112(C9): C09004.

McCormac FG. 1992. Liquid scintillation counter characterization, optimization and benzene purity correction. Radiocarbon 34(1):37-45.

McIntyre C, Sylva S. 2008. Gas chromatograph-combustion system and method for mass spectrometry. Provisional Patent US 61/197,047.

McManus JF, Francois R, Gherardi J-M, Keigwin LD, Brown-Leger S. 2004. Collapse and rapid resumption of Atlantic meridional circulation linked to deglacial climate changes. Nature 428(6985):834-7.

McNichol AP, Schneider RJ, von Reden KF, Gagnon AR, Elder KL, Key RM, Quay PD. 2000. Ten years after the WOCE AMS radiocarbon program. Nuclear Instruments and Methods in Physics Research B 172(14):479-84.

Middleton R, Adams CT. 1974. A close to universal negative ion source. Nuclear Instruments and Methods 118(2):329-36.

Middleton R, Klein J. 1999. Production of metastable negative ions in a caesium sputter source: verification of the existence of $\mathrm{N}_{2}^{-}$and $\mathrm{CO}^{-}$. Physical Review A 60(5):3786-99.

Mollenhauer G, Eglinton TI, Ohkouchi N, Schneider RR, Müller PJ, Grootes PM, Rullkötter J. 2003. Asynchronous alkenone and foraminifera records from the Benguela Upwelling System. Geochimica et Cosmochimica Acta 67(12):2157-71.

Mollenhauer G, Kienast M, Lamy F, Meggers H, Schneider R, Hayes JM, Eglinton TI. 2005a. An evaluation of ${ }^{14} \mathrm{C}$ age relationships between co-occurring foraminifera, alkenones, and total organic carbon in continental margin sediments. Paleoceanography 20(1): PA1016, doi: 10.1029/2004PA001103.

Mollenhauer G, Montluçon D, Eglinton TI. 2005b. Radiocarbon dating of alkenones from marine sediments: II. Assessment of carbon process blanks. Radiocarbon 47(3):413-24.

Mollenhauer G, McManus JF, Benthien A, Müller PJ, Eglinton TI. 2006. Rapid lateral particle transport in the Argentine Basin: molecular ${ }^{14} \mathrm{C}$ and ${ }^{230} \mathrm{Th}_{\mathrm{xs}}$ evidence. Deep-Sea Research Part I 53(7):1224-43.

Mook WG. 1983. International comparison of proportional gas counters for ${ }^{14} \mathrm{C}$ activity measurements. $\mathrm{Ra}$ diocarbon 25(2):475-84.

Mościcki W, Zastawny A. 1977. New proportional counter assembly in Gliwice ${ }^{14} \mathrm{C}$ laboratory. In: Povi- 
nec P, Usačev S, editors. Low-Radioactivity Measurements and Applications. Proceedings of the International Conference, High Tatras, 1975. Bratislava: Slovenské Pedagogické Nakladatestvo. p 91-2.

Muller RA. 1977. Radioisotope dating with a cyclotron. Science 196(4289):489-94.

Muller RA. 1978. Radioisotope dating with the LBL 88" Cyclotron. In: Gove HE, editor. Proceedings of the First Conference on Radiocarbon Dating with Accelerators. Rochester: University of Rochester. p 33-7. Available at http://homepage.univie.ac.at/walter.kutschera/AMS/AMS-1.pdf.

Muller RA, Alvarez LW, Holley WR, Stephenson ER. 1977. Quarks with unit charge: a search for anomalous hydrogen. Science 196(4289):521-52.

Muller RA, Tans PP, Mast TS, Welch JJ. 1981. Mass spectrometry with a very small cyclotron. In: Henning W, Kutschera W, Smitherand R, Yntema JL, editors. Proceedings of the Second International Conference on AMS. Argonne National Laboratory, Physics Division, ANL/PHY-81-1. p 342-5. Available at http:// homepage.univie.ac.at/walter.kutschera/AMS/AMS2.pdf.

Münnich KO, Vogel JC. 1958. Durch Atomexplosionen erzeugter Radiokohlenstoff in der Atmosphäre. Naturwissenschaften 45(14):327-9. In German.

Murnick DE, Dogru O, Ilkmen E. 2008. Intracavity optogalvanic spectroscopy. An analytical technique for ${ }^{14} \mathrm{C}$ analysis with subattomole sensitivity. Analytical Chemistry 80(13):4820-4.

Naegler T, Levin I. 2006. Closing the global radiocarbon budget 1945-2005. Journal of Geophysical Research 111(D12): doi: 10.1029/2005JD006758.

Nelson DE, Korteling RG, Stott WR. 1977. Carbon-14: direct detection at natural concentrations. Science 198(4316):507-8.

Noakes JE, Isbell AF, Stipp JJ, Hood DW. 1963. Benzene synthesis by low temperature catalysis for radiocarbon dating. Geochimica et Cosmochimica Acta 27(7): 797-804.

Noakes JE, Kim SM, Stipp JJ. 1965. Chemical and counting advances in liquid scintillation radiocarbon dating. In: Chatters RM, editor. Proceedings of the Sixth International Conference Radiocarbon and Tritium Dating. Pullman, Washington, 7-11 June 1965 (Conf. 650652). p 68-98.

Noakes JE, Neary MP, Spaulding JD. 1973. Tritium measurement with a new liquid scintillation counter. $\mathrm{Nu}$ clear Instruments and Methods 109(1):177-87.

Nydal R. 1962. Proportional counting technique for radiocarbon measurements. Review of Scientific Instruments 33:1313-20.

Nydal R, Lövseth K. 1965. Distribution of radiocarbon from nuclear tests. Nature 206(4988):1029-31.

Nydal R, Sigmond RS. 1957. Radiocarbon dating in Trondheim. Applied Scientific Research B 6:393-400.

Nydal R, Gulliksen S, Lövseth K. 1977. Proportional counters and shielding for low-level gas counting. In: Povinec P, Usačev S, editors. Low-Radioactivity Measurements and Applications. Proceedings of the International Conference Bratislava, 1975. Bratislava: Slovenské Pedagogické Nakladatestvo. p 13-22.

Oeschger H. 1963. Low level counting methods. In: $R a$ dioactive Dating. Vienna: IAEA. p 13.

Oeschger H, Loosli HH. 1977. New developments in sampling and low level counting of natural radioactivity. In: Povinec P, Usačev S, editors. Low-Radioactivity Measurements and Applications. Proceedings of the International Conference High Tatras, 1975. Bratislava: Slovenské Pedagogické Nakladatestvo. p 1322.

Oeschger H, Wahlen M. 1975. Low-level counting techniques. Annual Review of Nuclear Science 25:423-63.

Ohkouchi N, Eglinton T, Hayes J. 2003. Radiocarbon dating of individual fatty acids as a tool for refining Antarctic margin sediment chronologies. Radiocarbon 45(1):17-24.

Oliphant ML, Harteck P, Rutherford E. 1934. Transmutation effects observed with heavy hydrogen. Nature 133(3359):413.

Olsson IU. 1957. A C ${ }^{14}$ dating station using the $\mathrm{CO}_{2}$ proportional counting method. Arkiv för Fysik 13:37-60.

Olsson IU, editor. 1970. Radiocarbon Variations and $A b$ solute Chronology. Nobel Symposium 12, Uppsala, 11-15 August 1969. New York: John Wiley \& Sons.

Olsson IU, Karlen I, Turnbull AH, Prosser NJD. 1962. A determination of the half-life of ${ }^{14} \mathrm{C}$ with a proportional counter. Arkiv för Fysik 22:237-55.

Oppo DW, McManus JF, Cullen JL. 2003. Palaeo-oceanography: deepwater variability in the Holocene epoch. Nature 422(6929):277-8.

Östlund HG. 1957. Stockholm natural radiocarbon measurements I. Science 126(3272):493-7.

Otlet BI, Huxtable G, Evans GV, Humphreys DG, Short TD, Conchie SJ. 1983. Development and operation of the Harwell small counter facility for the measurement of ${ }^{14} \mathrm{C}$ in very small samples. Radiocarbon 25(2):565-75.

Patrut A, von Reden KF, Lowy DA, Alberts AA, Pohlman JW, Wittmann R, Gerlach D, Xu L, Mitchell CS. 2007. Radiocarbon dating of a very large African baobab. Tree Physiology 27(11):1569-74.

Peacock S. 2004. Debate over the ocean bomb radiocarbon sink: closing the gap. Global Biogeochemical Cycles 18(2): GB2022, doi: 10.1029/2003GB002211.

Pearson A, McNichol AP, Schneider RJ, von Reden KF, Zheng Y. 1998. Microscale AMS ${ }^{14} \mathrm{C}$ measurement at NOSAMS. Radiocarbon 40(1):61-75.

Pearson A, McNichol AP, Benitez-Nelson BC, Hayes JM, Eglinton TI. 2001. Origins of lipid biomarkers in Santa Monica Basin surface sediment: a case study using compound-specific $\Delta^{14} \mathrm{C}$ analysis. Geochimica et Cosmochimica Acta 65(18):3123-37.

Pearson GW. 1979. Precise ${ }^{14} \mathrm{C}$ measurement by liquid 
scintillation counting. Radiocarbon 21(1):1-21.

Plastino W, Kaihola L. 2006. Radiocarbon measurement by liquid scintillation spectrometry at the Gran Sasso National Laboratory. In: Povinec PP, Sanchez-Cabeza $\mathrm{JA}$, editors. Radionuclides in the Environments. Proceedings of the International Conference on Isotopes in Environmental Studies Monaco 2004. Amsterdam: Elsevier. p 520-8.

Polach H, Calf G, Harkness D, Hogg A, Kaihola L, Robertson S. 1988. Performance of new technology liquid scintillation counters for ${ }^{14} \mathrm{C}$ dating. Nuclear Geophysics 2:75-9.

Povinec P. 1972a. Very low background proportional counter for tritium dating. Nuclear Instruments and Methods 101(3):613-4.

Povinec P. 1972b. Preparation of methane gas for proportional ${ }^{3} \mathrm{H}$ and ${ }^{14} \mathrm{C}$ counters. Radiochemical and Radioanalytical Letters 9:127-35.

Povinec P. 1978. Multiwire proportional counters for low-level ${ }^{14} \mathrm{C}$ and ${ }^{3} \mathrm{H}$ measurements. Nuclear Instruments and Methods 156(3):441-6.

Povinec P. 1979. A study of proportional counter optimisation for long-term counting. Nuclear Instruments and Methods 163(2-3):363-8.

Povinec P. 1980. Proportional chambers for low level counting. Nuclear Instruments and Methods 176(12):111-7.

Povinec P. 1981. Simultaneous activity and background measurement by the same detector. International Journal of Applied Radiation and Isotopes 32(10): 729-32.

Povinec P. $1992 .{ }^{14} \mathrm{C}$ gas counting: Is there still a future? Radiocarbon 34(3):406-13.

Povinec P, Šáro Š, Chudý M, Šeliga M. 1968. The rapid method of radiocarbon counting in the atmosphere. International Journal of Applied Radiation and Isotopes 19(12):877-81.

Povinec PP, Betti M, Jull AJT, Vojtyla P. 2008. New isotope technologies in environmental physics. Acta Physica Slovaca 58:1-154.

Pringle RW, Turchinetz W, Funt BL. 1955. Liquid scintillation techniques for radiocarbon dating. Review of Scientific Instruments 26:859-65.

Pringle RW, Turchinetz W, Funt BL, Danyluk SS. 1957. Radiocarbon age estimates obtained by an improved liquid scintillation technique. Science 125(3237):69-

Purser KH. 1977. An Ultra-Sensitive Mass Spectrometry Apparatus. Filed 1 March 1976, US Patent No. 4,037,100.

Purser KH, Handley PR. 1978. A carbon-14 dating system. In: Gove HE, editor. Proceedings of the First Conference on Radiocarbon Dating with Accelerators. Rochester: University of Rochester. p 165-86. Available at http://homepage.univie.ac.at/walter.kutschera/AMS/AMS-1.pdf.

Purser KH, Liebert RB, Litherland AE, Beukens RP, Gove HE, Bennett CL, Clover MR, Sondheim W.
1977. An attempt to detect stable $\mathrm{N}^{-}$ions from a sputter ion source and some implications of the results for the design of tandems for ultra-sensitive carbon analysis. Revue de Physique Appliquée 12:1487-92.

Raeth CH, Sevold BJ, Pederson CN. 1951. A multipleanode anticoincidence ring counter. Review of Scientific Instruments 22:461-3.

Rafter TA, Fergusson GJ. 1957. The atom bomb effect recent increase in the carbon-14 content of the atmosphere, biosphere and surface waters of the ocean. New Zealand Journal of Science and Technology B 38: 871-3.

Rasmussen TL, Oppo DW, Thomsen E, Lehman SJ. 2003. Deep sea records from the southeast Labrador Sea: ocean circulation changes and ice-rafting events during the last 160,000 years. Paleoceanography 18(1): doi: 10.1029/2001PA000736.

Reddy CM, Eglinton TI, Hounshell A, White HK, Xu L, Gaines RB, Frysinger GS. 2002a. The west Falmouth oil spill after thirty years: the persistence of petroleum hydrocarbons in marsh sediments. Environmental Science \& Technology 36(22):4754-60.

Reddy CM, Pearson A, Xu L, McNichol AP, Benner Jr BA, Wise SA, Klouda GA, Currie LA, Eglinton TI. 2002b. Radiocarbon as a tool to apportion the sources of polycyclic aromatic hydrocarbons and black carbon in environmental samples. Environmental Science \& Technology 36(8):1774-82.

Reddy CM, Xu L, O'Neil GW, Nelson RK, Eglinton TI, Faulkner DJ, Norstrom R, Ross PS, Tittlemier SA. 2004. Radiocarbon evidence for a naturally produced, bioaccumulating halogenated organic compound. Environmental Science \& Technology 38(7):1992-7.

Reid AF, Dunning JR, Weinhouse S, Grosse AV. 1946. Half-life of ${ }^{14}$ C. Physical Review 70:431.

Reynolds GT, Harrison FB, Salvini G. 1950. Liquid scintillation counters. Physical Review 78:488.

Roberts ML, Schneider RJ, von Reden KF, Wills JSC, Han BX, Hayes JM, Rosenheim BE, Jenkins WJ. 2007. Progress on a gas-accepting ion source for continuous-flow accelerator mass spectrometry. Nuclear Instruments and Methods in Physics Research B 259(1):83-7.

Robinson LF, Adkins JF, Keigwin LD, Southon J, Fernandez DP, Wang S-L, Scheirer DS. 2005. Radiocarbon variability in the western North Atlantic during the last deglaciation. Science 310(5753):1469-73.

Rosenheim BE, Swart PK. 2007. Caribbean sclerosponge radiocarbon measurements re-interpreted in terms of U/Th age models. Nuclear Instruments and Methods in Physics Research B 259(1):474-8.

Ruben S, Kamen MD. 1941. Long-lived radioactive carbon: ${ }^{14}$ C. Physical Review 59:349-54.

Russell JM, Johnson TC. 2007. Little ice age drought in equatorial Africa: intertropical convergence zone migrations and El Niño-Southern oscillation variability. Geology 35(1):21-4.

Russell JM, Johnson TC, Talbot MR. 2003. A 725 yr cy- 
cle in the climate of central Africa during the late Holocene. Geology 31(8):677-80.

Rutherford E. 1937. The search for the isotopes of hydrogen and helium of mass 3. Nature 140(3538):303-5.

Schlosser P, Kromer B, Ekwurzel B, Bonisch G, McNichol A, Schneider R, von Reden K, Östlund HG, Swift JH. 1997. The first trans-Arctic ${ }^{14} \mathrm{C}$ section: comparison of the mean ages of the deep waters in the Eurasian and Canadian basins of the Arctic Ocean. Nuclear Instruments and Methods in Physics Research B 123(14):431-7.

Schneider RJ, Hayes JM, von Reden KF, McNichol AP, Eglinton TI, Wills JSC. 1998. Target preparation for continuous flow accelerator mass spectrometry. $\mathrm{Ra}$ diocarbon 40(1):95-102.

Schnitzer RW, Aberth H, Anbar M. 1975. In: Proceedings of the 23rd ASMS Annual Conference on Mass Spectrometry and Allied Topics. p 479-81.

Schoch H, Bruns M, Münnich KO, Münnich M. 1980. A multicounter system for high precision carbon-14 measurements. Radiocarbon 22(2):442-7.

Schwartzschild AZ, Thieberger P, Cumming JB. 1977. Bulletin of the American Physical Society 22:94.

Scott EM, editor. 2003. The Third International Radiocarbon Intercomparison (TIRI) and the Fourth International Radiocarbon Intercomparison (FIRI), 19902002. Results, analyses, and conclusions. Radiocarbon 45(2): 135-408.

Skog G. 2007. The single stage AMS machine at Lund University: status report. Nuclear Instruments and Methods in Physics Research B 259(1):1-6.

Slater GF, White HK, Eglinton TI, Reddy CM. 2005. Determination of microbial carbon sources in petroleum contaminated sediments using molecular ${ }^{14} \mathrm{C}$ analysis. Environmental Science \& Technology 39(8):2552-8.

Slater GF, Nelson RK, Kile BM, Reddy CM. 2006. Intrinsic bacterial biodegradation of petroleum contamination demonstrated in situ using natural abundance, molecular-level ${ }^{14} \mathrm{C}$ analysis. Organic Geochemistry 37:981-9.

Smittenberg RH, Baas M, Green MJ, Hopmans EC, Schouten S, Sinninghe Damsté JS. 2005. Pre- and post-industrial environmental changes as revealed by the biogeochemical sedimentary record of Drammensfjord, Norway. Marine Geology 214(1-3):177200.

Southon JR, Nelson DE, Vogel JS. 1990. Injection systems for AMS: simultaneous versus sequential. $\mathrm{Nu}$ clear Instruments and Methods in Physics Research B 52(3-4):370-4.

Srdoč D, Planinič J, Obelić B. 1977. A multiwire proportional counter for tritium and radiocarbon measurements. In: Povinec P, Usačev S, editors. Low-Radioactivity Measurements and Applications. Proceedings of the International Conference, High Tatras, 1975. Bratislava: Slovenské Pedagogické Nakladatestvo. p 67-70.
Srdoč D, Obelić B, Horvatinčić N. 1983. Radiocarbon dating of millimole-sized gaseous samples. Radiocarbon 25(2):485-92.

Starik LE, Arslanov KA, Zharkov AP. 1961. Radiokhimia 2:67

Starik LE, Arslanov KA, Klener IR. 1963. Radiokhimia 5:198.

Stephenson EJ, Alvarez LW, Clark DJ, Gough RA, Holley RA, Jain WR, Muller RA. 1977. Bulletin of the American Physical Society 22:579.

Stoenner RW, Schaeffer OA, Davis Jr R. 1960. Meteorites as space probes for testing the spatial constancy of cosmic radiation. Journal of Geophysical Research 65(10):3025-34.

Stuiver M. 1978. Carbon-14 dating: a comparison of beta and ion counting. Science 202(4370):881-3.

Stuiver M, van der Plicht J, editors. 1998. INTCAL98 Calibration Issue. Radiocarbon 40(3):1041-164.

Stuiver M, Robinson SW, Yang IC. $1979 .{ }^{14} \mathrm{C}$ dating to 60,000 years BP with proportional counters. In: Berger R, Suess HE, editors. Radiocarbon Dating. Proceedings of the Ninth International Conference Los Angeles and La Jolla, 1976. Berkeley: University of California Press. p 202-15.

Stuiver M, Long A, Kra RS, editors. 1993. Calibration 1993. Radiocarbon 35(1):1-244.

Suess HE. 1954. Natural radiocarbon measurements by acetylene counting. Science 120(3105):5-7.

Suess HE. 1965. Secular variations of the cosmic-rayproduced carbon 14 in the atmosphere and their interpretations. Journal of Geophysical Research 70(23): 5937-52.

Suess HE. 1980. The radiocarbon record in tree rings of the last 8000 years. Radiocarbon 22(2):200-9.

Suess HE. 1986. Secular variations of cosmogenic ${ }^{14} \mathrm{C}$ on Earth: their discoveries and interpretation. Radiocarbon 28(2A):259-65.

Suter M, Balzer R, Bonani G, Wölfli W. 1984. A fast beam pulsing system for isotope ratio measurements. Nuclear Instruments and Methods in Physics Research B 5(2):242-6.

Suter M, Döbeli M, Grajcar M, Müller A, Stocker M, Sun G, Synal H-A, Wacker L. 2007. Advances in particle identification in AMS at low energies. Nuclear Instruments and Methods in Physics Research B 259(1): 165-72.

Sweeney C, Gloor E, Jacobson AR, Key RM, McKinley G, Sarmiento JL, Wanninkhof R. 2007. Constraining global air-sea gas exchange for $\mathrm{CO}_{2}$ with recent bomb ${ }^{14} \mathrm{C}$ measurements. Global Biogeochemical Cycles 21: GB2015, doi: 10.1029/2006GB002784.

Synal H-A, Jacob S, Suter M. 2000. The PSI/ETH small radiocarbon system. Nuclear Instruments and Methods in Physics Research B 172(1-4):1-7.

Synal H-A, Stocker M, Suter M. 2007. MICADAS: a new compact radiocarbon AMS system. Nuclear Instruments and Methods in Physics Research B 259(1): 
7-13.

Tamers MA. 1965. Routine carbon-14 dating using liquid scintillation techniques. Acta Cientifica Venezolana 16:156-62.

Tamers MA, Pearson FJ. 1965. Isotope effect in the benzene synthesis for radiocarbon dating. Nature 205(4977):1205-7.

Tamers MA, Stipp JJ, Collier J. 1961. High sensitivity detection of naturally occurring radiocarbon-I Chemistry of the counting sample. Geochimica et Cosmochimica Acta 24(3-4):266-76.

Tanner RL, Parkhurst WJ, McNichol AP. 2004. Fossil sources of ambient aerosol carbon based on ${ }^{14} \mathrm{C}$ measurements. Aerosol Science and Technology 38(12): 133-9.

Tanner SD, Baranov VI, Bandura DM. 2002. Reaction cells and collision cells for ICP-MS: a tutorial review. Spectrochimica Acta B 57(9):1361-452.

Tans PP, de Jong AFM, Mook WG, Hut G. 1982. High accuracy carbon-14 counting and the application to the radiocarbon calibration curve. In: Povinec P, editor. Proceedings of the 2nd International Conference on Low-Level Counting. Volume 1. Bratislava: Veda Publishers. p 155-69.

Teuten EL, Xu L, Reddy CM. 2005. Two abundant bioaccumulated halogenated compounds are natural products. Science 307(5711):917-20.

Vogel JS, Southon JR, Nelson DE. 1987. Catalyst and binder effects in the use of filamentous graphite for AMS. Nuclear Instruments and Methods in Physics Research B 29(1-2):50-6.

von Reden KF, McNichol AP, Pearson A, Schneider RJ. 1998. ${ }^{14} \mathrm{C}$ AMS measurements of $<100 \mu \mathrm{g}$ samples with a high-current system. Radiocarbon 40(1):24753.

von Reden KF, Peden JC, Schneider RJ, Bellino M, Donoghue J, Elder KL, Gagnon AR, Long P, McNichol AP, Morin T, Stuart D, Hayes JM, Key RM. 1999. High-precision measurements of ${ }^{14} \mathrm{C}$ as a circulation tracer in the Pacific, Indian, and Southern oceans with accelerator mass spectrometry. AIP Conference Proceedings 473:410-21.

von Reden K, Roberts M, Han B, Schneider R, Wills J. 2007. Searching for a suitable gas ion source for ${ }^{14} \mathrm{C}$ accelerator mass spectrometry. AIP Conference Proceedings 925(1):341-5.

von Reden KF, Roberts ML, Jenkins WJ, Rosenheim BE, McNichol AP, Schneider RJ. 2008. Software development for continuous-gas-flow AMS. Nuclear Instruments and Methods in Physics Research B 266(10): 2233-7.

Wakeham SG, McNichol AP, Kostka JE, Pease TK. 2006. Natural-abundance radiocarbon as a tracer of assimilation of petroleum carbon by bacteria in salt marsh sediments. Geochimica et Cosmochimica Acta 70(7): 1761-71.

Wanninkhof R. 1992. Relationship between wind speed and gas exchange over the ocean. Journal of Geophysical Research 97(C5):7373-82.

Watson JT, Roe DK, Selenkow HA. 1965. Iodine-129 as a "non-radioactive" tracer. Radiation Research 26: 159-63.

Weidman C, Jones G. 1993. A shell-derived time history of bomb ${ }^{14} \mathrm{C}$ on Georges Bank and its Labrador Sea implications. Journal of Geophysical Research 98(C8):14,577-88.

Weinman JA, Cameron JR. 1956. Negative hydrogen ion source. Review of Scientific Instruments 27:288-93.

White HK, Reddy CM, Eglinton TI. 2005. Isotopic constraints on the fate of petroleum residues sequestered in salt marsh sediments. Environmental Science \& Technology 39(8):2545-51.

Zencak Z, Klanova J, Holoubek I, Gustafsson Ö. 2007. Source apportionment of atmospheric PAHs in the western Balkans by natural abundance radiocarbon analysis. Environmental Science \& Technology 41(11):3850-5. 